\title{
Stock Market Development, Banks and Firms Growth: Empirical Evidence from Saudi Arabia
}

\author{
Najeb Masoud ${ }^{1}$ \& Glenn Hardaker ${ }^{2}$ \\ ${ }^{1}$ Department of Accounting and Finance, Middle East University Business School, Jordan \\ ${ }^{2}$ National Teaching Fellow (HEA) and Development of Innovation Management, University of Huddersfield \\ Business School, United Kingdom \\ Correspondence: Najeb Masoud, Department of Accounting and Finance, Middle East University Business \\ School, Jordan, ON., po box 383 Amman, Jordan. Tel: 962-78-632-0186. E-mail: najeb2000@gmail.com
}

Received: February 25, 2014

Accepted: March 12, 2014

Online Published: May 25, 2014

doi:10.5539/ijef.v6n6p159

URL: http://dx.doi.org/10.5539/ijef.v6n6p159

\begin{abstract}
This study provides new and updated empirical investigate the effect of stock market development, banks development and firms growth using Saudi Arabia industrial firm-level data set for the period (1995-2013) and applying GMM, MG techniques technique model developed for dynamic panels. The econometric results reveal that with more development in the stock market firms that use equity finance heavily grow faster than firms that do not. These findings provide firm-level support for the proposition that the development of the stock market facilitates economic growth in Saudi Arabia. Our results also show that both the stock market and the banking sector development are significant in facilitating the firm's growth in Saudi Arabia. In particular, we find that measures of both market and banking development independently predict firm's growth when entered together in firm growth regressions. The results are consistent with the hypothesis that the stock market and the banking sector development have different effects on small and large firms.
\end{abstract}

Keyword: Saudi Arabia, stock market development, bank development, firm growth, GMM, MG techniques model

\section{Introduction}

This study provides new and updated empirical investigate the effect of stock market development, bank development and firms growth, taking Saudi Arabia as a country-specific case study and making use of macro data sets. Specifically, we provide a firm-level test of the hypothesis that the development of the stock market is a significant determinant of economic growth in Saudi Arabia. To the best of our knowledge, this is the first study which attempts to examine empirically the effect of stock market development, bank development and firms' growth using firm-level data within a specific developing country experience. Firm-level data analysis is important since in an environment with uncertainty and market imperfections, the manner in which the firm finances its operation influences and is affected by the level and efficiency of its investment. By justifying the adverse consequences of market imperfection (Note 1), financial markets could be mitigate these problems by performing various functions. They aggregate mobilise capital, enhance liquidity, provide risk pooling and sharing services, assess and select projects and management through producing information and monitor inside decision making.

In this study we construct a simple empirical model in which stock market development and bank development affects firm growth through enhancing productivity growth within the firm. Specifically, utilising corporate financial theory, we argue that stock markets provide risk sharing, enhancing liquidity and promote responsible governance and control through providing outside investors with a variety of mechanisms for monitoring inside decision makers. This, in turn, facilitates technological innovations and improves the economic efficiency with which the firm utilises its resources, and therefore, contributes to higher productivity growth. However, in our empirical model, we assume that the degree to which firms benefit from stock market functions depends on how much firm relies on the stock market to finance its investment. Thus, our empirical model predicts that firms which rely more on equity finance will benefit more from stock market development and banking sector.

Empirically, the particular questions we attempt to address in this study are as follows. Do firms that depend 
heavily on equity finance grow at a faster rate than firms that do not depend heavily on equity finance when the stock market becomes more developed? Are the banks or the stock market better at providing financial services and promoting the growth of Saudi Arabia firms, or is the overall financial development critically significant in influencing the firms' growth? Are the stock market developments and the banking sector development in providing financial services to the corporate sector in Saudi Arabia? And how do developments within the banking sector and the stock market have different effects on the growth of large and small firms?.

Our analysis is carried out with the Generalised-Method of Moments (GMM) for panel data utilising instrumental variable. One advantage of using panel data over congenital cross-sectional or time-series data sets is that it usually stretches a large number of observations, which increases the degrees of freedom and reduce the multicollinearity among explanatory variables, hence, improving the efficiency of econometric estimates, (Hsiao, 1985, 1986; Appelbe et al., 1992; Ahn \& Schmidt, 1999; Baltagi et al., 2007; Hair et al., 2009; Tachiwou, 2010; Siqueira et al., 2012). Furthermore, it is generally argued that the production function may actually differ across firms. It is empirically difficult for single cross-sectional approach to allow for such differences in the production function. Thus, the most a significant advantage in using the panel data approach is that it allows for the difference in the production function across firms in the form of unobservable individual "firm effects".

We use two GMM dynamic panel estimators. These estimators specifically address econometric problems induced by firm specific effects and predetermined explanatory variables (endogeneity). The fact that the model explanatory variables implies endogeneity and autocorrelation. Likewise, using this type of data may give rise to heteroscedasticity. Therefore, GMM enables consistent estimation in spite of heteroscedasticity and autocorrelation (Stock, 2001), which would blur the results if a method like Ordinary Least Squares (OLS), fixed or within estimators was used by (Johnston \& DiNardo, 1997; Blundell et al., 2000; Andrews \& Lu, 2001; Ariyo \& Adelegan, 2005; Ewah et al., 2009; Rogers et al., 2008; Hoberg \& Phillips, 2012). Furthermore, GMM is particularly suitable for panel containing numerous firms and a small number of time periods developed by (Holtz-Eakin et al., 1990; Arellano \& Bover, 1995; Bond et al., 1999). In order to address the possible omitted variable bias created by firm-specific effects in the first GMM dynamic panel estimator we difference the regression equation. Thus, we take differences to eliminate firm-specific effects and thereby remove variable bias. Then, we instrument the right-hand side variables (the differenced value) of the original regressors using lagged values of original regressors (measured in levels) as instruments. This last step removes the inconsistency arising from simultaneity bias.

The problem with the difference estimator is that it generally suffers from weak instruments, mainly, lagged values of the levels of the original regressors which frequently make weak instruments for the differenced values of the regressors used in panel equations. This shortcoming may induce large biases in finite samples and poor precision when the series are persistent (Blundell \& Bond, 1998a). To mitigate this problem, we use a system GMM estimator developed by Arellano and Bover (1995), Blundell and Bond (1998b). This estimator controls for the presence of unobserved firm-specific effects and for the endogeneity of the current-dated explanatory variables. Besides the difference panel equations where the instruments are lagged levels of the original regressors, this estimator this estimator simultaneously estimates the original levels equation where the instruments are lagged values of the differenced regressors. Thus, to investigate our issues in this study, we use the GMM dynamic panel technique with both a difference and system estimator (Doorenik et al., 1999).

The sequence of the rest of the study is structured as follows. This present section, Section 1, is the introduction section presenting the aims and questions of the study, the underlying theory and the methodology used. Section 2 elaborates the theoretical background and previous empirical literature. Section 3 provides outlines the theoretical model framework. Section 4 introduces the empirical model and the hypotheses to be investigate. Section 5 describes the data and methodology. The empirical model results are reported in Section 6. Section 7 concludes as well as provides policy implications of the study.

\section{Theory and Related Literature}

There is currently a lack of published material and, in some areas the existing empirical literature is rather limited. Therefore, this study will provide a contribution to the subject of the relationship between stock market development, bank development and firms' growth by providing an analysis of sufficient data at the firm-level (especially for developing countries). Nevertheless, the endogenous growth literature and research, and recent theoretical studies have tried to provide a link between the literature of endogenous growth theory and financial markets (Note 2). Providing evidence of stock market development will assist policy makers in designing reforms that do indeed promote the growth rate, enhancing stock market development as economic growth through to the banking system of financial sectors, and to the degree of investor's right; furthermore, allowing 
risk sharing encourages speculative and productive investment (see e.g., Greenwood \& Jovanovic, 1990; Bencivenga \& Smith, 1991).

Demirgüç-Kunt and Maksimovic $(1998,2001)$ provide micro-level support for the proposition that financial development facilitates economic growth using firm-level data from developed and developing countries. In their work they used firm-level data and they focused on international (between-country) differences rather than on national, between-firm differences. Using two indicators for stock market development, the ratio of market capitalisation to GDP and turnover ratio and one indicator for banking sector development, the ratio of asset deposit banks to GDP; Demirgüç-Kunt \& Maksimovic run cross-country regressions and find that there is a strong relationship between the development of financial markets and banks and the proportion of firms growing at rates requiring long-run external financing. They concluded that firms in countries that have easier access to external funds (e.g., active stock markets and high ratings for compliance with legal norms) tend to grow faster. Greenwood \& Smith (1997) argued that large stock markets create facilities in investments in the very productive technological areas. They further advocate that the facility providers are supplying these services at lower rates. Because the large stock market firms have many customers, their returns remain the same, or even higher, than those holding small capital in the stock markets.

Levine (1997), Beck et al. (1999), Levine et al. (2000) used the ratio of total bank assets to GDP which are relative to the size of the economy and the value of credit provided by the banking sector to the private sector divided by GDP. Whilst some authors stress the significant relationship between banks and stock markets (Stiglitz, 1985; Boyd \& Prescott, 1986; Bhide, 1993), other empirical studies consider the impact of banks and stock market development on economic growth. These include: Atje and Jovanovic (1993), Jappelli and Pagano (1994), Harris (1997), Levine (1997), Levine and Zervos (1998), Boyd and Smith (1998), Huybens and Smith (1998), Rousseau and Wachtel (2000), Levine (2003), Beck and Levine (2002), Bekaert et al. (2005), Demirgüç-Kunt and Levine (2008). Dow and Gorton (1997), Stiglitz (1989), Collier and Maryer (1989), Cobham (1995) argued from a different perspective and supported banks rather than stock markets, particularly with regard to the situation in developing countries. The same concepts were further agreed by (Singh, 1993, 1996, 1997, 1999) where it was advocated that stock markets inflicted greater damage upon developing economies in comparison to banks.

Saint-Paul (1992) presents a model that provides financial market interaction within the technological choice of firms in that financial market which allow riskier but more productive activity and technological choice in turn will affect the viability of financial markets. Dow and Gorton (1995) offered a model which argued that, if the primary role of the stock market is to signal information for assessment financing and monitoring, banks may be equally effective at efficient resource allocation. Also, King \& Levine (1993) were unable to proffer a distinction of the differences between the stock market and banks. As far as physical accumulation is concerned, both stock markets and banks provide sources of external financing for firms (Note 3). For the function of resource allocation, both stock market and banks create information to equal the allocation of resources. They differ only in the manner that information is transmitted in a stock market and contained in equity prices, whilst that in banks is collected by loan managers. Demirgüe-Kunt and Huizinga (2000) used bank-level data from 80 developed and developing countries over the 1990-1997 period. They investigated whether there is any relationship between bank performance and the level of stock market development. They found that the larger market capitalisation to GDP increases bank profits and interest margins to reflect possible complementary balance between banks and stock markets. They concluded that the stock market may improve bank sector performance as, for instance, stock markets generate useful information about firms and banks.

Demirgüç-Kunt and Maksimovic (1996) argued that stock market development could affect a firm's financial choices and investment decisions by using two classes: firstly, the incapacity of inventors and entrepreneurs to diversify their portfolio optimally in stock markets; secondly, the asymmetric information problems that occur because stock markets do not perform the information production function efficiently. Blackburn and Hung (1998), claim that financial institutions, on one hand, lower the agency costs that must be paid by privately informed firms to secure loans for undertaking research projects. They present a theoretical analysis of the two-way causal relationship between growth and financial development by focusing on the role of financial institutions as delegated checking agencies which appear endogenously to provide the most efficient means of channelling savings into investment. Hao et al. (2011) find that less profitable firms within an industry are more sensitive to industry-wide update than their more profitable counterparts, in particular for capital-intensive sector. Finally, Boyd and Smith (1998) assert that the absence of stock markets would prevent firms from employing their most productive capital technologies.

From all the above we can argue that the degree to which stock market influence firm growth depends mainly on 
how effectively they carry out both its allocation and governance functions. A stock market that simply serves as a conduit of capital provision would not be effective in accelerating growth; equally important is the information production and control role. Capital mobilising and information production have a critical role in enhancing firm growth through impact on the productivity growth component; facilitation of risky technological advances and improving economic efficiency with which the firm utilises its resources. Patrick \& Wai (1973) explained that markets were established to finance firms that were has been used in short-term of finance due to technological change and to finance government expenditures in the developed world economy.

\section{Theoretical Model Framework}

Following microeconomic growth theory, we postulate that the firm employs a bundle of resources or inputs to produce output, we base this on the traditional production function which consists of four variables: output $(Y)$ capital $(K)$, labour $(L)$ and total factor productivity $(A)$ which has two components: economic efficiency and the level of technological progress. The neoclassical production function is defined as follows (Barro, 1998).

$$
Y_{i, t}=f\left(A_{i, t}, K_{i, t}, L_{i, t}\right)
$$

Where $i$ and $t$ denote firm and time subscript, respectively. Differentiating the Eq. 1 with respect to time we obtain Eq. 2:

$$
Y_{i, t}=\frac{\partial Y_{i, t}}{\partial A_{i, t}} A_{i, t}+\frac{\partial Y_{i, t}}{\partial K_{i, t}} K_{i, t}+\frac{\partial Y_{i, t}}{\partial L_{i, t}} L_{i, t}
$$

Where a dot denotes a time derivative and $\partial Y_{i, t} / \partial A_{i, t}$, and $\partial Y_{i, t} / \partial K_{i, t}$ denote $\left[\partial Y_{i, t} / \partial\left(A_{i, t} K_{i, t}\right)\right] K_{i, t}$ and $\left[\partial Y_{i, t} / \partial\left(A_{i, t} K_{i, t}\right)\right] A_{i, t}$ respectively. Dividing sides by $\partial Y_{i, t}$ and rewriting yields:

$$
\frac{Y_{i, t}}{Y_{i, t}}=\frac{A_{i, t}}{Y_{i, t}} \frac{\partial Y_{i, t}}{\partial A_{i, t}} \frac{A_{i, t}}{\partial A_{i, t}}+\frac{K_{i, t}}{Y_{i, t}} \frac{\partial Y_{i, t}}{\partial K_{i, t}} \frac{K_{i, t}}{K_{i, t}}+\frac{L_{i, t}}{Y_{i, t}} \frac{\partial L_{i, t}}{\partial L_{i, t}} \frac{L_{i, t}}{L_{i, t}} \cong \beta_{i}^{K} \frac{K_{i, t}}{K_{i, t}}+R_{i, t}+\beta_{i}^{L} \frac{L_{i, t}}{L_{i, t}}
$$

Where $\beta_{i}^{K}$ and $\beta_{i}^{L}$ are the elasticity of output with respect to capital $(K)$ and labour $(L)$, respectively. $R_{i, t}$ reflects the total source of growth other the contribution of capital and labour, which represents what is called growth in total productivity $(T F P)$.

Based on Eq. 3 one could be distinguish between growth that follows from increases in total factor productivity and growth that arise from increases in the firm's factor stock. This later growth includes the standard factors of production, labour and capital. Factor productivity may change due to shifts in the underlying technology and changes in the economic efficiency of the production process. We extend the firm growth model (Eq. 3) to incorporate stoic $\mathrm{k}$ market effects and other elements by using the hypothesis that $R_{i, t}$ can be expressed as a function of stock market factor $\left(S M F_{i, t}\right)$ and a vector of variable $X_{i, t}$. Since the degree to which the firm benefits from the stock market is based on the degree of its presence in the stock market through raising equity, the stock market factor $\left(S M F_{i, t}\right)$ in total factor productivity growth will therefore be the interaction between the stock market development and the firm's dependence on equity finance. Thus, our hypothesis is based on the argument that firms that are heavily users of equity finance should benefit excessively more from greater stock market development than firms that are not weighty users of equity finance. That is to say $R_{i, t}$ can be expressed as follows:

$$
R_{i, t}=f\left(S M F_{i, t}, X_{i, t}\right)
$$

To be able to isolate the effects of the stock market effect, the $X_{i, t}$ vector should ideally consist of all other factors that affect firm productivity growth. For instance, variables which measure competitive conditions, organisational influence, labour relation, labour market regulations, external network, managerial ability, firm strategy and ownership structure, may be a significant (see e.g., Storey, 1994; Delmar, 1997; Davidsson \& Henrekson, 2000). However, due to data limitations at the firm level in Saudi Arabia stock market we include only three variables that may affect firm total productivity growth: the age of the firm, the product market completion and the ownership structure. Hence, (Masoud \& Gleen, henceforth MG) consider first basic model used to test the impact of the stock market development on the firm's growth is a dynamic panel data model specified as: 


$$
\begin{aligned}
& y_{i, t}=\gamma_{1} y_{i, t-1}+\gamma_{2} G K_{i, t}+\gamma_{3} G L_{i, t}+\gamma_{4-9} S M F_{i, t}+\gamma_{10} A G E_{i, t}+\gamma_{11} C O M_{i, t}+ \\
& \gamma_{12} O W N_{i, t}+\alpha_{i, t}+\varepsilon_{i, t}
\end{aligned}
$$

$i=1, \ldots, N ; t=1, \ldots, T+7$.

where $Y_{i, t}$ is firm's growth rate of real value added at time $i(18$-years) time period. Value added is defined as operating profits after depreciation plus wages and interest payments. $G K_{i, t}$ and $G L_{i, t}$ are the growth rate of real capital stock and the number of employees, respectively. The capita stock is defined as the book value of total assets. The number of employees is used because data does not allow us to use a more precise definition (e.g., total working hours). $\left(\gamma_{4-9} S M F_{i, t}\right)$ is the stock market factor measured by multiplying the dependence on equity finance for firm $i$ at time $t$ with the stock market development indicator at time $t$. A firm's dependence on equity finance is defined as the proportion of total firm's investment expenditure that has been financed by new equity issue. Additionally, another variable $\left(\gamma_{4-5} B A N K_{i, t}\right)$ that measures banking sector development is added to the basic empirical model as in Eq. 5 and Eq. 6. If the coefficient estimate of the stock market development indicator $\left(\gamma_{4-9} S M F_{i, t}\right)$ is still significant and relatively stable after including the banking sector development indicator $\left(\gamma_{4-5} B A N K_{i, t}\right)$, this may imply that the stock market and banking sector are complementary rather than substitutes in providing financial services to the developing country in general, and the Saudi Arabia economy in particular. The scales of the coefficient estimate of stock market and banking sector development indicators provide a measure with an indicator about the significance of stock market development in comparison with banking sector development in enhancing the firm's growth.

Among other things, $A G E_{i, t}$ is defined as the firm age. $C O M_{i, t}$ is the inverse competition indicator, defined as the ratio of ex-post rent (profit minus capital cost) to value added. $O W N_{i, t}$ is the ownership concentration ratio, measured by the percentage of shares controlled by large shareholders who own 10 per cent or more of the firm. $\alpha_{i, t}$ is an unobserved firm specific effect with captures any common period specific effects. $\varepsilon_{i, t}$ is the time-varying error term, represents those effects which cannot be controlled by the firm, such as business cycle, equity and access to labour, labour market conflicts, measurement errors in the independent variable, and other explanatory variables that have been omitted. It is assumed to be independently and identical normally distributed with zero mean and constant variance, $\left(\varepsilon_{i, t} \approx i i d N\left(0, \sigma_{\varepsilon}^{2}\right)\right)$ and $y_{i, 0}=0$. Absence of serial correlation is assisted by the inclusion of dynamics in the form of a lagged dependent variable. The literature on lagged dependent variables is vast and varied; some of the most important articles are those by Lee et al. (1998), Islam (1998). Following work suggested by Islam (1998), MG included the lag (one-year) of the dependent variables in MG model to capture the fact that whenever factors of production are changed it typically takes some time for output to reach its new long-run level. For instance, if new capital goods are purchased it may take a considerable time before the machines are fully effective.

In order to examine the stock market and the banking sector as direct sources of capital and mechanisms for monitoring that the investors have access to information about firms'. Consequently, MG added to the basic regression another financial variable $\left(D M F_{i, t}\right)$, measured by multiplying the dependence on debt finance for firm $i$ at time $t$ by the banking sector development indicator at time $t$. A firm's dependence on debt finance is defined as the proportion of the total firm's investment expenditure that has been financed by debt (short and long-run debt). If the coefficient estimated for the interaction of equity dependence and the stock market development is still significant after including the new financial variables $\left(D M F_{i, t}\right)$, this implies that the stock market and the banking sector are complementary rather than substitutes providing different financial services to the Saudi Arabia corporate sector. The magnitudes of the estimated coefficients of the two variables (the stock market and the debt market factors) provide us with an indicator about the significance of the stock market development compared with banking sector development in fostering the firm's growth.

To investigate the hypothesis that the stock market and banking sector development may have different effects on large and small firms' growth, therefore, that the stock market development has greater effects on large than large firms and that the banking sector development effects small firms more than large firms, MG create a dummy variable (DUM) equal to one if the firm is large and zero if small. The large firm is defined as the firm that has total assets above the median of the total assets of the firm sample. MG interacted this dummy variable with the stock market factor $(S M F)$ and the debt market factor $(D M F)$. MG then included these two new variables in the regression equation. If the estimated coefficients of $\left(D U M^{*} S M F\right)$ and/or $\left(D U M^{*} D M F\right)$ enter significantly in the regressions estimate, this implies that the stock market and banks have different effects on large and small firms. If the coefficient of $\left(D U M^{*} D M F\right)$ enters positive and significant, this implies that the stock market impacts on large firms more than small firms that are dependent on equity finance. If the coefficient of $\left(D U M^{*} D M F\right)$ enters negative and significant, it implies that the banking sector development effects small 
firms more than large firms that are dependent on debt finance.

\section{Econometric Methods}

MG use two econometric techniques, mainly to control the simultaneity biases that may arise from the joint determination of the financial markets development and firm's growth (endogeneity of the level of the financial market development) and also to eliminate any omitted variable bias induce by firm-specific effects. As well now known estimating dynamic panel regression models which contain many firms and a small number of time periods the OLS estimator are not consistent because of the following econometric problems, the possible correlation between unobserved firm-specific effects and other explanatory variables, the potential correlation between the lagged endogenous variables and residuals and the possibility that explanatory variables are not exogenous. In panel data estimation, consistent estimates of coefficients depend on the stochastic properties of the model. If the error term is orthogonal to the right hand side variables, an OLS estimator will be consistent. Otherwise, if all explanatory variables are strictly exogenous, then a fixed effect estimator will be consistent. The equation model MG estimate here contains unobservable firm fixed effects, which are correlated with explanatory variables as well as endogenous variables. Hence, the orthogonality conditions between the error terms and the variables are not likely to be met for an OLS or fixed effect estimator to produce consistent estimators (Blundell \& Bond, 1998a, b; Nerlove, 2000).

One could be achieve the orthogonality conditions under certain circumstances through appropriate differencing of the equation. Therefore, in MG empirical model we have a lagged dependent variables as well as possible endogenous variables as regressors. Furthermore, the error terms in the differenced equations are correlated with the lagged dependent variables through contemporaneous terms in period $t+j$ if there was no unobserved firm or time fixed effects that correlate with the regressors. Likewise, the fixed effect estimator that can be account for corrected fixed effects as well as account for the possibility of endogeneity of regressors is therefore needed. Chamberlian (1984) has proposed a generalised method of moment's (GMM) estimator that allows the regressors to be transformed to achieve orthogonality between them and error terms (more detailed see Matyas, 1999). While the GMM estimator can account for firm heterogeneity, it does not account for the endogeneity of regressors. The dynamic growth effects may introduce auto-regression in error structure. For instance, Arellano and Bond (1991) have proposed a dynamic panel estimator that optimally exploits the linear moment restrictions implied by the dynamic panel model, MG developed this model using in this study. This method uses all past values of endogenous regressors as well as lagged values of all strictly exogenous regressors as instruments. Thus MG use this method to estimate Eq. 5, the regression equation after taking the first-difference of Eq. 5 (Note 4) can be written as GMM methods:

$$
\begin{aligned}
& \Delta y_{i, t}=\gamma_{1} \Delta y_{i, t-1}+\gamma_{2} \Delta G K_{i, t}+\gamma_{3} \Delta G L_{i, t}+\gamma_{4-9} \Delta S M F_{i, t}+\gamma_{10} \Delta A G E_{i, t}+ \\
& \gamma_{11} \Delta C O M_{i, t}+\gamma_{12} \Delta O W N_{i, t}+\Delta \varepsilon_{i, t}
\end{aligned}
$$

Where $\Delta$ is the first-difference operator; $\Delta y_{i, t}=y_{i, t}-y_{i, t-1}$. Given that the $\varepsilon_{i, t}$ are serially uncorrelated, the GMM is the most efficient one within the class of instrumental variable estimators were first proposed by Anderson and Hsiao (1981, 1982). Griliches and Hausman (1986) have developed estimators for errors in variables models whose identification relies on assumptions of lack of or limited serial correlation in the measurement errors. In estimating (Eq. 6), $y_{i, t-2}$ or higher lagged values (wherever feasible) are valid instrumented variables. Thus typically the coefficient estimates of the parameter vector $\theta=\left(\gamma_{1}, \ldots, \gamma_{7}\right)$ are given by:

$$
\theta_{G M M}=\left(x^{\prime} \mathrm{wa}_{n} \mathrm{w}^{\prime} \mathrm{X}\right)^{-1} \quad\left(x^{\prime} \mathrm{wa}_{n} \mathrm{w}^{\prime} \Delta \mathrm{y}\right)
$$

Where $X$ is the vector of the first differenced explanatory variables, $\mathrm{w}$ is the matrix of instrumental variables, $a_{n}$ is the weighting matrix and $\Delta y$ is the (NT X 1) vector of the first-differences of firm's growth rates. Under the assumptions that there is no serial correlation in the error term $\varepsilon$ and that the explanatory variables are weakly exogenous, in the sense that they are assumed to be uncorrelated with future realisation of error the term, the following moment conditions apply to the lagged dependent variables and set of explanatory variables:

$$
E\left[y_{i, t-s}, X_{i, t-s}\left(u_{i, t} \Delta u_{i, t-1}\right)\right]=0 \text { for } \mathrm{s} \geq 2 ; \mathrm{t}=3,4, \ldots \mathrm{T}
$$

$u_{i, t}=\alpha_{i}+\varepsilon_{i, t}, i=1, \ldots, N ; t=1, \ldots, T$.

Arellano and Bond (1991) propose a two-step GMM estimator using an estimated variance-covariance matrix formed from the residual of a preliminary consistent estimate of $\theta_{t}$. In other words, in the one-step they assumed that the error terms are independent and homoscedastic across firms and over time. In the two-step, they used the residuals obtained from the one-step construct a consistent estimate of the variance-covariance matrix, thus relaxing the assumption of independence and homoscedasticity. Thus, two-different choices for $a_{n}$, result in two a linear GMM estimators model. The one-step estimator of the parameter of interest is obtained by minimising: 


$$
a_{n}=\left(\frac{1}{N} \sum_{i=1}^{N} w_{i}^{\prime} \Delta u_{i}\right)^{-1}
$$

where

$$
W_{i}=\left[\begin{array}{ccccccc}
y_{i 0} & 0 & 0 & \cdots & 0 & \cdots & 0 \\
0 & y_{i 0} & y_{i 1} & \cdots & 0 & \cdots & 0 \\
0 & 0 & 0 & \ddots & 0 & \cdots & 0 \\
0 & 0 & 0 & \cdots & y_{i 0} & \cdots & y_{i, T-2}
\end{array}\right]
$$

A two-step estimator is found by letting:

$$
a_{n}=\left(\frac{1}{N} \sum_{i=1}^{N} w_{i}^{\prime} \Delta \hat{u}_{i}\right)^{-1}
$$

Where $\Delta \hat{u}_{i}$ is the residuals from a consistent one-step estimator of $\Delta y$. MG use the two-step estimator to estimate the coefficients of the firm's growth model and MG will refer to this estimator as the difference estimator. However, Blundell and Bond (1998b) show that when the lagged dependent and the explanatory variables are persistent over time, lagged levels of these variables are weak instruments for the regression equation in differences. The instruments' weaknesses have repercussions on both the asymptotic variance and the small-sample performance of the difference estimator. As the variables persistence increases the asymptotic variance of the coefficients obtained with the difference estimator rise. Furthermore, according to Blundell et al. (2000) simulation studies suggest that the difference estimator has a large finite-sample bias and poor precision, especially with samples which have a small time series dimension.

To confront these econometric problems, MG also used the GMM system estimator developed by Arellano and Bover (1995), Blundell and Bond (1998b). These estimators combined the regression in differences with the regression in levels. The instruments for the regression in differences are the same as above i.e., the lagged levels of the corresponding variables, so that, the instant conditions in (Eq. 8) apply to the first part of the system. The instruments for the regression in the levels are the lagged differences of the corresponding variables. The latter are valid instruments under the following additional assumption; although there might be a correlation between the level of the right-hand-side variables and the firm-specific effects in Eq. 5, there is no correlation between the differences of these variables and the firm-specific effects:

$$
E\left[y_{i, t+p} \alpha_{i}\right]=E\left[y_{i, t+q} \alpha_{i}\right] \text { and } E\left[X_{i, t+p} \alpha_{i}\right]=E\left[X_{i, t+q} \alpha_{i}\right] \text { for all } \mathrm{p} \text { and } \mathrm{q}
$$

While, the following forms give the additional moment conditions for the second part of the system (the regression in levels):

$$
E\left[\left(y_{i, t+s}-y_{i, t+s-1}\right) ;\left(X_{i, t+s}-X_{i, t+s-1}\right)\left(\alpha_{i}+\varepsilon_{i, t}\right)\right]=0 \text { for } \mathrm{s}=1
$$

For this estimator (system of equations), in first-differences and levels, the one-step uses the following weighting matrix:

$$
W_{i}=\left(\begin{array}{cc}
w_{i}^{D} & 0 \\
0 & I_{i}
\end{array}\right)
$$

where $w_{i}^{D}$ is the weighting matrix described above for the first-differenced estimator and $I_{i}$ is an identity matrix with a dimension equal to the number of level equations observed for individual $i$. In both cases the corresponding two-step estimator uses Eq. 10. Thus, MG will use the GMM system estimator to generate consistent and efficient estimators of the parameters of interest. However, the consistency of the GMM estimator depends on the assumption that the lagged value of the firm's value added growth and the other explanatory variables are valid instruments in the growth regression and that the error terms do not exhibit serial correlation. To address these MG perform three tests proposed by Arellano and Bond (1991), Arellano and Bover (1995), Blundell and Bond (1998a, b). The first test examines the hypothesis that the error term is not serially correlated. In both the difference regression and the system difference-level regression MG test whether the differenced error term is second-order serially correlated (see e.g., Sargan, 1958; Hansen, 1982). These test the overall validity of the instruments and for the GMM estimator in the first-differenced model this test statistic takes the following form:

$$
s_{d}=\frac{1}{N} \Delta \hat{e_{i}} w_{i}^{\prime} \alpha_{n} w_{i}^{\prime} \Delta \hat{e_{i}}
$$


where $\alpha_{n}$ is the optimal weight matrix as in (Eq.10) and $\Delta \hat{e}_{i}$ are the two-step residuals in differenced model. Under the null-hypothesis of validity of the instruments this test is distributed $\chi^{2}$ with degrees of freedom calculated as the difference between the number of instruments and the number of regressors. For the system estimator, the same test is readily defined. The third test is that difference Sargan statistic, which tests the additional set of restrictions of the system estimator. This test is obtained as the difference between the first-difference and the system Sargan statistics. This statistic test is asymptotically distributed as $\chi^{2}$ under the null-hypothesis of validity of the additional instruments. The degree of freedom of the difference Sargan test is given by the number of additional restrictions in the system estimator, which is given by the difference estimator. Failure to reject the null-hypothesis of both tests gives support to MG model specification.

\section{Data and Sample}

This section provides the data sources, sample selection, variables measurement and summary statistical analysis.

\subsection{Data Sources and Sample Selection}

MG entire industrial firm's data set of publicly traded companies of the years 1995 to 2013 are obtained from the "Gulf Investment Guide issued by Zughaibi \& Kabbani Financial Consultants in Jeddah, and Tadawl" published annually by the Saudi Arabia Stock Market (TASI) since its establishment in 1984. Companies listed at the TASI are required to submit certain data and a copy of their annual reports to TASI. Data related to these companies are compiled from these reports, the TASI, and other resources and then published in the "Guide and Tadawl" to present a close approximation of companies annual overall operations. The purpose of the "Guide and Tadawl" is to provide information about these companies for those who are concerned, especially for investors at the TASI. In the early 1995 and the end 2013, the "Guide and Tadawl" includes information about 159 companies listed in the TASI, out of them 28 are (Petrochemical and Investment) industrial companies. Therefore, MG sample company data set includes all 28 industrial companies over an 18-years period of time in a balanced panel with no missing values for the variables under investigation. It may be useful to note here that the industrial companies included in MG simple are highly diversified and operating in a number of unrelated fields.

To highlight the economic significance of the sample companies included, Saudi Arabia wealth has grown strongly amongst the country's small population due to oil price increases. Economic development has two significant factors: a high value/low employment energy sector and a low value/high employment non-energy sector. The size of the informal economy is estimated at 30-40 per cent of GDP. Saudi Arabia has the distinctive characteristic of having been reliant on the oil industry for its economy since the development of oil production in the mid-1940s. Oil is the major source of income and almost all foreign currency. Oil revenues comprise over 90-95 per cent of Saudi Arabia hard currency earnings (about 70 per cent of government receipts and 30 per cent of the gross domestic product). As a percentage of gross domestic products, the total value added of these companies accounted for about 12 per cent during the period 1995-2013. As a percentage of industrial value added, which represents about 19 per cent of the GDP, the total value for MG sample accounted for about 27 per cent during the same period. Finally, the total market capitalisation of these companies accounted, on average for about 16.8 per cent of GDP, about 24 per cent of total market capitalisation and about 58 per cent of market capitalisation of the industrial sector the period 1995-2013.

\subsection{Measurement and Data Summary Statistical Analysis}

The firm-specific variables are measured as organise: the firm's real growth rate measured as the ratio of value added in year +1 adjusted for inflation (using the CPI) to the value added in year 0 minus one (to measure growth rate). Similarly, the growth rate of capital expenditures is defined as the ratio of capital expenditures in year +1 adjusted for inflation to the capital expenditures in year 0 , minus one. The growth rate of employment is measured as the ratio of the number of employees in year +1 to the number of employees in year 0 , minus one. The ownership concentration ratio is measured by the percentage of shares controlled by large shareholders who own 10 per cent or more of the firm. Firm age is defined as the last year for which MG use data minus the year of establishment. Following work by Nickell (1996), MG use ex-post rents normalised on value added as an inverse measure of competition. The theoretical assumption under this measurement is that monopoly rents generated by firms decrease with more completion in the market (competition is associated with lower levels of rents generated) (Not 5). The cost of capital is equal to $r r+\delta+\lambda_{\rho}$, where $r r$ is the real interest rate (nominal interest rate on business loans minus the inflation rate), $\delta$ is the rate of depreciation assumed to be constant at 12 per cent (Not 6$), \rho$ is the risk premium equal to the firms market return less the short term interest rate (interest rate on three months SR certificates of deposits), $\lambda$ is a weight equal to equity/(equity + debt). 
In this study MG use four indicators to measure the stock market development and two indicators to measure the banking sector development. The development of the stock market is measured by the following indicator: the market capitalisation ratio equals the value of listed shares divided by GDP, the total value of shares traded ratio equals the total of shares traded on the market exchange divided by GDP, the turnover ratio equals the value of total shares traded divided by the value of shares listed and the stock market volatility measured as an annualised standard deviation that is based on weekly market returns. The banking sector development is measured by the ratio of total banking sector assets to GDP, and the value of credits to the private sector divided by GDP. MG include all of the indicators mentioned previous in their model regressions in logs instead of levels to allow for the nonlinearity in the relationship between financial development and growth illustrated by Levine et al. (2000), beck and Levine (2000), Masoud and Hardaker (2012). Likewise, MG use two types of interaction variables, the stock market factor $\left(S M F_{i, t}\right)$ and the debt market factor $\left(D M F_{i, t}\right)$. The stock market factor for firm $i$ at time $t$ is measured by multiplying the dependence on equity finance for firm $i$ at time $t$ with the stock market development indicator at time $t$. Similarly, the debt market factor from firm $i$ at time $t$ is measured by multiplying the dependence on debt finance for firm $i$ at time $t$ with the banking sector development indicators at time $t$.

Table 1 provides summary descriptive statistics of all variable measures in this study over the period 1995-2013. As can be seen from the Table, there is a large variance in the measurement of the firm-level characteristic variables. It is interesting to realise that our sample firms rely heavily on new issues of shares on the stock market to finance their investment. Table 1 shown that, equity finance contributes about 44.25 per cent the firms' total capital expenditures during the period 1995-2013. With regards to debt finance, it accounts for about 26.45 per cent of the firms' total capital expenditures during the same period. The remaining 26 per cent of firms' capital expenditures were financed internally. This evidence is not surprising and also not new. These new issues represented about 28 per cent of total private investment in the country during the period 1995-2013. More significantly, it is also consistent with the findings of Singh and Weisse (1998), Singh (1999). Whereas the mean firms' is 19 years old. These results confirm the idea that most of the firms in our sample are small but with some maturity. Therefore, under this result large firms are likely to be more dependent on equity finance and less dependent finance (Rajan \& Zingles, 1995; Shin \& Stulz, 2000; Pagano et al., 2002). Thus, changes in stock markets development are likely to have a more significant influence on large firms' growth than on the growth of smaller firm.

Table 1. Summary of sample statistics

\begin{tabular}{|c|c|c|c|c|c|}
\hline \multicolumn{2}{|l|}{ Sample period (1995-2013) } & \multirow{2}{*}{ Mean } & \multirow{2}{*}{ Median } & \multirow{2}{*}{$\mathrm{SD}$} & \multirow{2}{*}{ Jarque-Bera } \\
\hline Variables & Code & & & & \\
\hline Real growth rate of value added & $Y$ & 4.84 & 3.58 & 46.2 & $49.321(0.000)$ \\
\hline Growth rate of capital stock & $G K$ & 6.29 & 4.23 & 20.03 & $32.27(0.000)$ \\
\hline Growth rate of employment & $G L$ & 3.52 & 2.85 & 30.11 & $38.72(0.000)$ \\
\hline Firm's age & $A G E$ & 19.43 & 16.12 & 13.09 & $31.75(0.000)$ \\
\hline Inverse completion indicator & COM & 16.24 & 12.22 & 14.34 & $15.78(0.000)$ \\
\hline Ownership concentration ratio & OWN & 32.62 & 29.33 & 27.45 & $28.52(0.000)$ \\
\hline Equity dependence (finance) & $E D$ & 44.25 & 37.84 & 41.63 & $49.26(0.000)$ \\
\hline Debt dependence (finance) & $D D$ & 26.45 & 22.35 & 52.94 & $51.52(0.000)$ \\
\hline Stock market capitalisation ratio & $M C R$ & 59.98 & 57.79 & 21.34 & $1.982(-0.593)$ \\
\hline Stock market vale traded ratio & $V T R$ & 19.81 & 16.24 & 9.78 & $2.011(-0.392)$ \\
\hline Stock market turnover ratio & $T R$ & 17.64 & 15.73 & 12.49 & $3.288(-0.273)$ \\
\hline Stock market volatility & $V O L$ & 13.87 & 10.3 & 3.02 & $0.193(-0.896)$ \\
\hline Banks asset ratio /GDP & $B A R$ & 60.12 & 59.78 & 15.2 & $0.987(-0.432)$ \\
\hline Banks credit ratio to private to GDP & $B D R$ & 58.17 & 57.8 & 14.09 & $0.935(-0.642)$ \\
\hline
\end{tabular}

Note. P-values in parentheses.

Table 2 shows the correlation among the variables used in this study. The interaction of equity dependence and each of market capitalisation ratio, value-traded ratio and turnover ratio have a significant positive correlation with the firm's growth at the five per cent level. The interaction of equity finance and market volatility is negatively correlated with the firm's growth (significant at the five-per cent level). The interactions of debt dependence with the banking sector development indicators are positively and statistically significant (at the five-per cent level) correlated with firms' growth. The inverse measure of the consumption, age and the growth 
rate of employees are negatively and significantly correlated with firm's growth. Not surprisingly, the growth rate of capital expenditure and the ownership concentration ratio are positively and significantly correlated with firms' growth.

Table 2. Correlation among variables

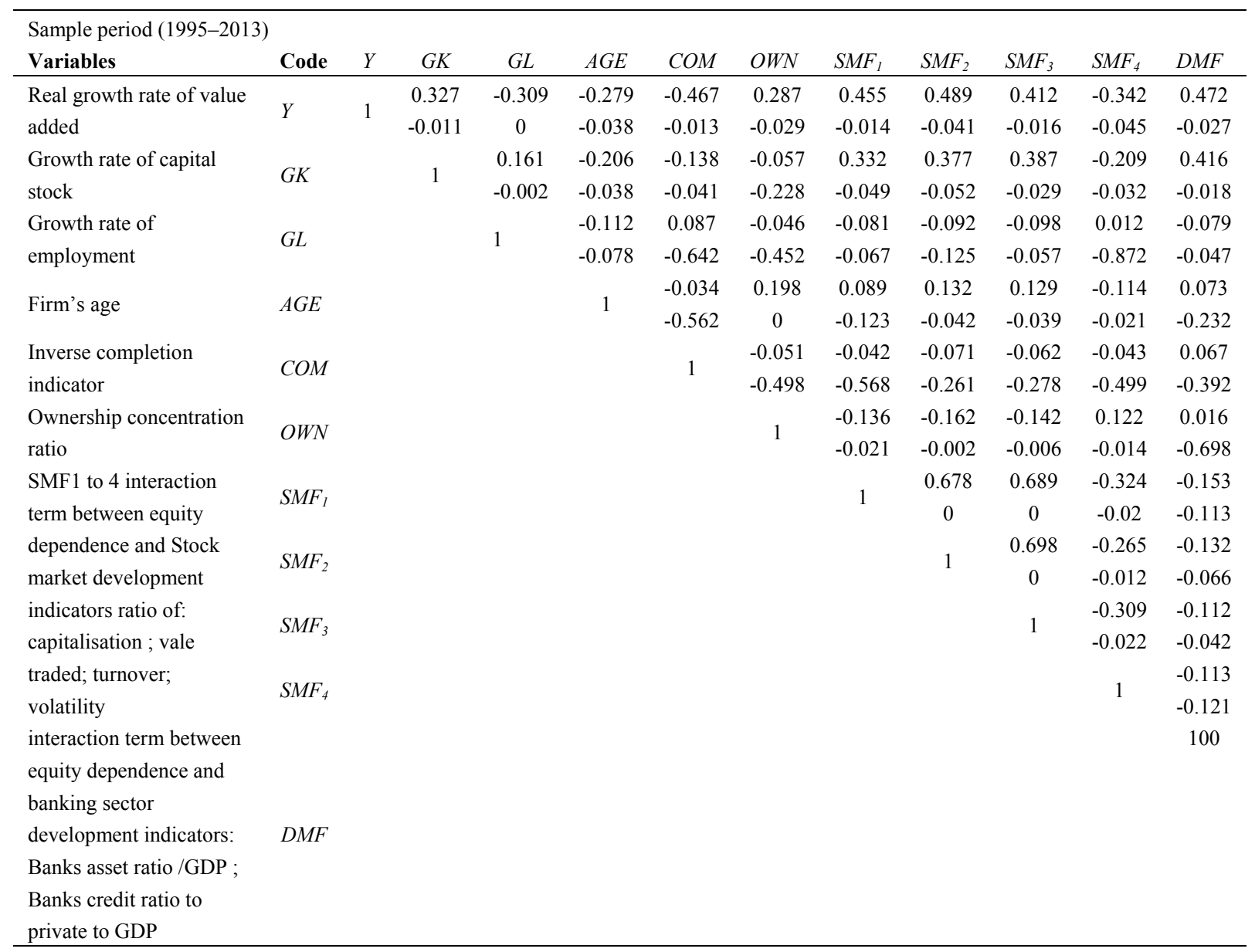

Note. P-values in parentheses.

\section{Empirical Model Result}

MG use lagged values of corresponding variables as instruments in the regression equation in differences and both the lagged levels and lagged differences of the explanatory variables in the system estimators. MG work with two lags in order to avoid cases for which there might be first-order autocorrelation of the residuals. This technique assumes that past values of the explanatory variables are uncorrelated with the contemporaneous error term. At the same time, past explanatory variables are correlated with the contemporaneous value of explanatory variables. The dynamic panel estimates suggest that financial sector development in Saudi Arabia influences on the firm's growth. Table 3 presents the results using the differences GMM dynamic-panel estimator. Table 4 gives the result from system GGM dynamic-panel estimation. In this case MG only present two-step GGM dynamic-panel estimators, since they are more efficient than one-step estimates and since only the Sargan test of over-identifying restrictions heteroscedasticity consistent only if based on the two-step estimates. As recommended by Beck and Levine (2002, p. 20), in small samples, this adjusted measure seems to offer a reasonable compromise, especially if the system runs by Sargan and serial correlation tests.

The Tables present asymptotic $t$ statistics calculated from heteroscedasticity consistent standard errors associated with the GMM estimates, statistics for Sargan tests and test statics for first and second order serial correlation. The model's goodness of fit statistics indicates that fits the data very well, in all regressions. MG rejects the null-hypothesis that the variations in the dependent variable cannot be explained by the explanatory variables as indicated by $\chi^{2}$ static of the joint of significant. The key elements condition MG exploit in our estimates is the 
lack of serial correlation among error terms. The test statistics presented in Table 3 and 4 indicate that MG cannot reject the null-hypothesis of the absence of first or second order serial correlation (by using the differenced equation exhibit no k-order serial correlation). The Sargan tests of over identifying restriction indicate that MG cannot reject the null-hypothesis that there is no correlation between the error terms and the instrument vector and that the models are correctly specified. Therefore, the results of system estimate are similar to those generated by difference estimates, the difference Sargan test for the validity of additional instruments does support the use of the GMM system estimator. These results imply that differences in the right-hand side variables are not correlated with the unobserved firm-specific effects, so that MG can assume that the additional restrictions used in the system estimation hold.

Tables 3 and 4 shown that the coefficients of the regressions estimated by GMM difference estimator have relatively similar order of magnitude as the coefficients of the regressions estimated by GMM system estimator. The growth rate of capital expenditure has a large and significant positive correlation with the firm growth at the one-per cent level or better. The growth rate of the number of employees has a small and significantly negative correlation with growth, for instance, Bottazzi et al. (2006) show that firms with one employee radically differ from firms with two or more employees in terms of production structure. This result may be explained by the effect of diminishing returns of labour productivity that arises mainly from low capital-labour ratios, inadequate skills and short work-experience of young labour force. The results also suggest that older firms' have lower growth (this result is consistent with Dune and Hughes (1994), Heshmmati (2001) results that found negative relationships between the growth and age of firms in the US, UK and Sweden. However, Das (1995) found age and growth to be positively related using India hardware computer industry). This supports the argument that older firms may have become petrified in some sense or may not have as strong an incentive as a younger firm to invest in new technology. Furthermore, due to vintage effects, a younger firm may become productive if its capital stock is more modern than the capital stock of an order firm. As MG expected, productive market competition and shareholder control have plausible effects on the firm's growth. More precisely, rents normalised on value added (an inverse measure of completion) are negatively related to the firms' growth, ownership concentration is positively related to future growth. The lagged dependent variable which captures the autoregressive nature of growth is positive and highly significant at the one-per cent level or better.

Given all the GMM results truly must address now, the main issue of the effect of the financial market development on a firm's performance in terms of value added growth. Column 1 of Tables (3) and (4) shows results for a firm's growth as a function of stock market factor $(S M F)$ and also other explanatory variables that appear in all the regressions, where the stock market development indicator in this interaction term is the market capitalisation as a percentage of the GDP. As can be seen, in both, the difference and the system dynamic panel growth regressions, the coefficients estimated for the stock market factor (the interaction of stock market capitalisation ratio and equity dependence) is positive ( 0.071 in the difference panel dynamic regression and 0.048 in the system dynamic panel regression) and highly significant at the one-per cent level or better. This result supports our hypothesis that firms that are heavily dependent on equity finance benefit from the greater stock market development than firms that are not heavily dependents on equity finance. This result also indicates that, for a given firm with a positive equity dependence ratio, the higher level of the stock market capitalisation results in a higher growth rate of the firms. This result is inconsistent with Levine \& Zervos $(1996,1998)$ in which they fail to find a relationship between stock market capitalisation and growth in per capita GDP, Rajan \& Zingales (1998) also fail to find market capitalisation as having effect on relative growth of financially dependent industries. However, this result is consistent with Demirgüç-Kunt \& Maksimovic $(1998,2001)$ finding at the firm-level.

To illustrate the significance of this result, MG consider the "differential in real growth rate" which indicates how much faster the firm at $90^{\text {th }}$ percentile of equity dependence (for instance, SAUDI INTERNATIONAL PEROCHEMICAL CO.) would have grown compared to the firm at the 25th percentile (for instance, ALABDULLATIF INDUSTRIAL INVESTMENT CO.). The coefficient estimates from the difference dynamic panel regression predicts that the, SAUDI INTERNATIONAL PEROCHEMICAL CO. would grow 2.6 percentage points faster than the (ALABDULLATIF INDUSTRIAL INVESTMENT CO.) (Note 7). This result therefore indicates that more development in the stock market ameliorates the market frictions and thereby promotes the growth of firms that rely more heavily on equity finance. This result also provides firm-level support and confirmation of proposition that the development of the stock market facilitates the economic growth in Saudi Arabia.

Column 2 of Tables 3 and 4 show the results for the firms' growth as a function of the stock market factor (the interaction of the market capitalisation ratio and equity dependence) and the debt market factor (the interaction 
of the banking sector development and debt dependence), where the banking sector development indicator in the interaction term is the ratio of credit to the private sector to GDP. The reason behind including the debt market factor in the regression is to control the effect of debt finance and more significantly to shed any light on the argument that the banking sector is either complementary or a substitute to the stock market in providing financial services to corporate finance and whether the banking sector or the stock market are better at fostering firm growth in Saudi Arabia.

The results from the regression show that the debt market factor (DMF) in both difference and the system dynamic panel growth regressions are positive and highly significant at the one-per cent level or better. This implies that firms heavily dependent on debt finance benefit more from the increased banking sector development than firms that are not heavy uses of debt finance. The results also imply that, for a given firm with a positive growth rate of this firm. Further significantly, as can seen from the Tables, the coefficient estimates for the stock market factors are still highly significant and stable after including the debt market factor $(0.072$ in the difference panel dynamic regression and 0.031 in the system dynamic panel regression). This implies that the existence of a development stock market as well as a development banking sector is important in determining firm's growth in Saudi Arabia. In other words, the results indicate that firms that are heavy users of external finance growth faster with the higher overall levels of financial development. This result is consistent with the findings of Beck and Levine (2000) that industries that are heavily dependent on external finance grow faster in economics with a higher level of overall financial development.

This result also suggests that the stock market and the banking sector in Saudi Arabia play different, yet complementary, roles. They provide different bundles of services to the nonfinancial sector. If they are a substitute and provide the same financial services then they would not both enter the growth regressions significantly. Possible explanations of this result can be found in the theoretical literature, banks primarily ameliorate information asymmetries, while stock markets primarily enhance liquidity and facilities risk diversification. Thus, policies undertaken to develop the stock market need not adversely affect the existing banking system. MG results are also consistent with the findings of Masoud and Hardaker (2012) and the conclusion of Demirgüç-Kunt and Levine (1996), Demirgüç-Kunt and Maksimovic (1996), Boyd and Smith (1998), Demirgüç-Kunt and Maksimovic (2001) that stock market and financial intermediary development proceed simultaneously.

Likewise, when MG look to the estimated coefficients of the stock market factor and the debt market factor, MG find that the estimated coefficients of the interaction of equity dependence and all of each stock market development indicator used in this study are greater than the estimated coefficients of the interaction of debt dependence and the measure of the banking development in the both types of estimators. This implies that firms that are equity dependent with a greater development of the stock market thrive better than firms that are debt dependent with a greater development of the banking sector. As Levine (1991) argues, capital raised through equity issues is long-run, while the investor at short time can liquidate shares without impacting the firm's projects. By contrast, if the firm finances with non-tradable, finite maturity debt held by banks, shocks to the banks may be transmitted on the firm and force liquidation of long-run projects. To the extent that stock markets create a separation between the liquidity shocks of investors and the investment needs of firms, the latter can take a longer-term view and invest further efficiently.

Another possible explanation for the study results is that the development of the stock market effects the cost of capital and capital efficiency of all firms, not just the financially dependent ones, while the development of the banking sector affects firms dependent on debt finance only. For instance, better risk sharing, more liquidity and control attained through the equity market improve economic efficiency and reduce the cost of capital for all firms, not just the financially dependent ones. Additionally, the Saudi Arabia banks are not involved heavily with nonfinancial firms; they hold little shares and are more like Anglo-Saxon banks. Thus, the role of banking sector in Saudi Arabia, in the sense of an Anglo-Saxon-Style for corporate control, is limited. They predominantly monitor from a creditor's perspective. Another feature of the Saudi Arabia banking sector is the higher concentration ratio, where the share of three main banks in total assets is almost 91 per cent. A highly concentrated banking might reduce the ability to channel funds efficiently to firms (Beck et al., 1999). Deidda and Crenos (2000) argue that increase banks competition increase the efficiency of banks operating in the credit market and therefore higher growth (more detailed see e.g., Peterson \& Rajan, 1995; Cetorelli \& Gamberra, 2000; Stulz, 2000).

MG will now turn to the question of whether the stock market and the banking sector development enhances small and large firms differently. In this case, whether the changes in the stock market development have a more significant influence on large firms than on smaller ones and whether the changes in the banking sector 
development have more influence on small firms than on large firms. In order to test this hypothesis, in addition to the variables that MG included in the regressions in column 2, MG include another two variables, the first one is the interaction of stock market factor $(S M F)$ and dummy variables $(D M F)$ which equals to one if a firm is large and zero otherwise. A large firm is defined as having total assets greater than the sample median (in this study we have 12 large firms and 16 small firms). The second one is the interaction of the debt market factor $(D M F)$ and the firm size dummy variables mentioned previously.

The results are reported in column 4 of Tables (3) and (4). In both the difference and the system dynamic panel regressions, the results indicate a significantly positive integration of the stock market factor and firm size dummy variable $\left(S M F^{*} D U M\right)$ on firm growth. At the same time, the coefficients of the stock market factor in the regressions falls but are still significant at the five-per cent level. This result supports the argument that large firms display more sensitivity to the change in the stock market development than the small firms. In the same regression the coefficients on the interaction terms of debt market factor and the firm size dummy variables $\left(S M F^{*} D U M\right)$ are negative but insignificant at the five-per cent level in the system dynamic panel estimator. In these regressions, the coefficient of debt market factor $(D M F)$ rise and are still significant in both types of estimators. In general, this result confirms the view that small firms are more sensitive than large firms to the change in the banking sector development.

When MG use alternative measures of the stock market development and re-estimate the regression in column 2, MG still find a strong, causal relationship between the interaction of equity dependence and the stock market development and the firm's growth. The last three columns of Tables 3 and 4 percent these results where the stock market development indicators in the interaction terms are the value-traded ratio, turnover ratio and volatility, respectively. As can be seen, in columns 4 and 5, the coefficients on integration terms of equity dependence and the liquidity indicators, the value-traded ratio and turnover ratio, are significantly positive at the one-per cent level in both the difference and the system dynamic panel growth regressions. These results indicate that with more liquidity in the stock market, firms that equity finance heavily grow faster than firms that do not use equity finance heavily. These results are consistent with the pervious empirical studies.

These results confirm also the view that increased market liquidity will increase the effectiveness of the governess function of market and facilitate (risky) technological advances (Note 8), thereby improving total factor productive of firm, as described in Acemoglu et al. (2006) a country that is behind technological frontier will typically follow a capital accumulation growth. Increased market liquidity can improve the effectiveness of the governance function in two ways. First, increased market liquidity induced information acquisition, which in turn increases the information content of share prices. The more liquid the market, the easier it becomes for an investor, who has obtained information about a firm, to trade at posted prices. Thus, investor can profit before the information becomes widely a viable and the price changes (Kyle, 1984). If investors can profit from obtaining information they will be more likely to research and monitor. More liquidity in markets increases the incentive to research firms, thus the improved information will help firms to overcome problems of moral hazard. Second, the effective use of the takeover mechanism requires a liquid market where bidders access a vast amount of capital on short notice.

The last column of the Tables 3 and 4 present the result where the stock market development in the interaction term is the market volatility. The result indicates that the coefficient on interaction term enters negatively $(-0.052)$ and is significant at the one-per cent level in the difference dynamic panel growth regression. In the system dynamic panel growth regression the coefficient enters negative $(-0.061)$ but is insignificant at the five-per cent level. Thus, in general, MG can conclude that increases in the stock market volatility slow down the growth rates the firms that depend heavily on equity financing. As is well known, more volatility in stock prices increase the cost of equity capital to firms and also increases the value of the "option wait", hence delaying productive investment. Thus, the higher level of share prices volatility will impede the firms' growth, especially for those that heavily dependent on equity finance. 
Table 3. Stock market development and firms growth: difference dynamic panel regression

\begin{tabular}{|c|c|c|c|c|c|c|c|}
\hline \multicolumn{2}{|c|}{ GMM test; sample period (1995-2013) } & \multicolumn{6}{|c|}{ Dependent Variables $y_{i, t}{ }^{a}$} \\
\hline \multirow[t]{2}{*}{ Independent Variables } & \multirow[t]{2}{*}{ Code } & \multicolumn{3}{|c|}{ b } & \multicolumn{3}{|c|}{$\mathbf{c}$} \\
\hline & & 1 & 2 & 3 & 4 & 5 & 6 \\
\hline $\begin{array}{l}\text { Firm's growth rate of real value added } \\
\text { at time } t\end{array}$ & $y_{i, t-1}$ & $\begin{array}{c}0.392 \\
(75.08) \\
{[0.000]}\end{array}$ & $\begin{array}{c}0.394 \\
(73.96) \\
{[0.000]}\end{array}$ & $\begin{array}{c}0.383 \\
(59.02) \\
{[0.000]}\end{array}$ & $\begin{array}{c}0.393 \\
(13.20) \\
{[0.000]}\end{array}$ & $\begin{array}{c}0.391 \\
(89.47) \\
{[0.000]}\end{array}$ & $\begin{array}{c}0.395 \\
(77.02) \\
{[0.000]}\end{array}$ \\
\hline Growth of capital stock & $G K_{i, t}$ & $\begin{array}{c}0.421 \\
(5.25) \\
{[0.000]}\end{array}$ & $\begin{array}{l}0.408 \\
(5.06) \\
{[0.00]}\end{array}$ & $\begin{array}{l}0.421 \\
(6.89) \\
{[0.00]}\end{array}$ & $\begin{array}{c}0.393 \\
(5.32) \\
{[0.000]}\end{array}$ & $\begin{array}{c}0.423 \\
(5.16) \\
{[0.000]}\end{array}$ & $\begin{array}{c}0.388 \\
(5.12) \\
{[0.000]}\end{array}$ \\
\hline Number of employees & $G L_{i, t}$ & $\begin{array}{c}-0.0009 \\
(-12.02) \\
{[0.000]}\end{array}$ & $\begin{array}{c}-0.0015 \\
(-8.43) \\
{[0.000]}\end{array}$ & $\begin{array}{c}-0.0008 \\
(11.98) \\
{[0.000]}\end{array}$ & $\begin{array}{c}-0.0006 \\
(-12.10) \\
{[0.000]}\end{array}$ & $\begin{array}{c}-0.0007 \\
(-7.43) \\
{[0.000]}\end{array}$ & $\begin{array}{c}-0.0005 \\
(-3.56) \\
{[0.012]}\end{array}$ \\
\hline $\begin{array}{l}\text { Interaction between the firm equity the } \\
\text { stock market development }\end{array}$ & $S M F_{i, t}$ & $\begin{array}{l}0.071 \\
(6.55) \\
{[0.00]}\end{array}$ & $\begin{array}{c}0.072 \\
(11.20) \\
{[0.00]}\end{array}$ & $\begin{array}{c}0.069 \\
(3.01) \\
{[0.029]}\end{array}$ & $\begin{array}{c}0.118 \\
(2.43) \\
{[0.031]}\end{array}$ & $\begin{array}{c}0.162 \\
(2.56) \\
{[0.014]}\end{array}$ & $\begin{array}{l}-0.052 \\
(-3.26) \\
{[0.001]}\end{array}$ \\
\hline Firm's age & $A G E_{i, t}$ & $\begin{array}{c}-0.279 \\
(-1.75) \\
{[0.067]}\end{array}$ & $\begin{array}{c}-0.372 \\
(-1.68) \\
{[0.139]}\end{array}$ & $\begin{array}{c}-0.169 \\
(-1.51) \\
{[0.238]}\end{array}$ & $\begin{array}{l}-0.570 \\
(-7.12) \\
{[0.00]}\end{array}$ & $\begin{array}{c}-0.562 \\
(-5 .) \\
{[0.00]}\end{array}$ & $\begin{array}{c}-0.520 \\
(-6.11) \\
{[0.00]}\end{array}$ \\
\hline $\begin{array}{l}\text { Invers competition indicator (defined } \\
\text { as the ratio of ex-post rent to net sale) }\end{array}$ & $C O M_{i, t}$ & $\begin{array}{c}-0.410 \\
(-6.62) \\
{[0.000]}\end{array}$ & $\begin{array}{c}-0.322 \\
(-5.39) \\
{[0.000]}\end{array}$ & $\begin{array}{c}-0.368 \\
(-7.89) \\
{[0.000]}\end{array}$ & $\begin{array}{c}-0.201 \\
(-4.02) \\
{[0.000]}\end{array}$ & $\begin{array}{l}-0.601 \\
(-8.21) \\
{[0.000]}\end{array}$ & $\begin{array}{c}-0.612 \\
(7.98) \\
{[0.000]}\end{array}$ \\
\hline Ownership concentration ratio & $O W N_{i, t}$ & $\begin{array}{c}0.169 \\
(4.15) \\
{[0.000]}\end{array}$ & $\begin{array}{c}0.140 \\
(3.11) \\
{[0.002]}\end{array}$ & $\begin{array}{c}0.118 \\
(2.04) \\
{[0.017]}\end{array}$ & $\begin{array}{c}0.115 \\
(4.29) \\
{[0.000]}\end{array}$ & $\begin{array}{c}0.119 \\
(2.98) \\
{[0.026]}\end{array}$ & $\begin{array}{c}0.089 \\
(2.17) \\
{[0.072]}\end{array}$ \\
\hline $\begin{array}{l}\text { Interaction between the firm's } \\
\text { dependence on debt finance and bank } \\
\text { sector de. }^{\text {d }}\end{array}$ & $D M F_{i, t}$ & & $\begin{array}{c}0.017 \\
(5.82) \\
{[0.000]}\end{array}$ & $\begin{array}{c}0.079 \\
(4.99) \\
{[0.000]}\end{array}$ & $\begin{array}{c}0.014 \\
(5.01) \\
{[0.000]}\end{array}$ & $\begin{array}{c}0.018 \\
(6.33) \\
{[0.000]}\end{array}$ & $\begin{array}{c}0.13 \\
(4.09) \\
{[0.000]}\end{array}$ \\
\hline $\begin{array}{l}D U M_{i, t} \text { Firm's size dummy variable } \\
\text { equal } 1 \text { if the firm is large }\end{array}$ & $S M F_{i, t}{ }^{*} D U M_{i, t}$ & & & $\begin{array}{c}0.181 \\
(7.92) \\
{[0.000]}\end{array}$ & & & \\
\hline & $\underset{t}{D M F_{i, t}}{ }^{*} D U M_{i,}$ & & & $\begin{array}{l}-0.048 \\
(-11.62) \\
{[0.000]}\end{array}$ & & & \\
\hline $1^{\text {st }}$ Order serial correlation test ${ }^{\mathrm{e}}$ & $L M_{(l)}$ & [0.649] & {$[0.501$} & {$[0.602]$} & {$[0.589]$} & {$[0.629]$} & {$[0.610]$} \\
\hline $2^{\text {st }}$ Order serial correlation test ${ }^{\mathrm{e}}$ & $L M_{(2)}$ & {$[0.231]$} & {$[0.189]$} & {$[0.121]$} & {$[0.278]$} & $0.259]$ & {$[0.280]$} \\
\hline Joint significance test & $J T$ & {$[0.000]$} & {$[0.000]$} & {$[0.000]$} & {$[0.000]$} & {$[0.000]$} & {$[0.000]$} \\
\hline Sargan Test ${ }^{\mathrm{f}}$ & $S T$ & {$[0.682]$} & {$[0.691]$} & {$[0.690]$} & {$[0.690]$} & {$[0.879]$} & {$[0.889]$} \\
\hline
\end{tabular}

Note. Numbers in parentheses are t-values and numbers in Brackets are P-value. This Table reports the GMM-DIFFERENCE regression, estimated by using DPD99 package for OX. Time dummies are included in all the regressions.

Notices: ${ }^{\text {a: }}$ the dependent variable in all models is the growth rates of value added. Value added is defined as operating profits after depreciation plus wages and interest payments. ${ }^{\text {b: }}$ In regressions from 1 to 3 , the stock market development is the market capitalisation ratio. ${ }^{\mathrm{c}}$ In regression 4, 5 and 6 the stock market development are total vale-traded ratio, turnover ratio and volatility, respectively. ${ }^{\text {d: }}$ the bank sector developments are the ratio of total assets to GDP and the private credit to GDP. ${ }^{\text {e: }} L M_{(k)}$ is the test statistic for the presence of k-th order serial correlation in the first-differenced residual, the null-hypothesis is that the errors in the first-difference regression exhibit no k-order serial correlation. ${ }^{\text {f: }}$ Sargan is a Sargan test of the over identifying restrictions, the null-hypothesis is that the instruments used are not correlated with residuals. The joint test statistic is a test of the joint significance of all independent variables. 
Table 4. Stock market development and firms growth: difference dynamic panel regression, system estimator

\begin{tabular}{|c|c|c|c|c|c|c|c|}
\hline \multicolumn{2}{|c|}{ GMM test; sample period (1995-2013) } & \multicolumn{6}{|c|}{ Dependent Variables $y_{i, t}{ }^{\mathrm{a}}$} \\
\hline \multirow[t]{2}{*}{ Independent Variables } & \multirow[t]{2}{*}{ Code } & \multicolumn{3}{|c|}{ b } & \multicolumn{3}{|c|}{ c } \\
\hline & & 1 & 2 & 3 & 4 & 5 & 6 \\
\hline $\begin{array}{l}\text { Firm's growth rate of real value added } \\
\text { at time } t\end{array}$ & $y_{i, t-1}$ & $\begin{array}{c}0.210 \\
(39.62) \\
{[0.000]}\end{array}$ & $\begin{array}{c}0.214 \\
(39.66) \\
{[0.000]}\end{array}$ & $\begin{array}{c}0.173 \\
(20.21) \\
{[0.000]}\end{array}$ & $\begin{array}{c}0.187 \\
(16.03) \\
{[0.000]}\end{array}$ & $\begin{array}{c}0.212 \\
(23.65) \\
{[0.000]}\end{array}$ & $\begin{array}{c}0.219 \\
(36.42) \\
{[0.000]}\end{array}$ \\
\hline Growth of capital stock & $G K_{i, t}$ & $\begin{array}{c}0.298 \\
(1.72) \\
{[0.041]}\end{array}$ & $\begin{array}{l}0.301 \\
(2.28) \\
{[0.001]}\end{array}$ & $\begin{array}{c}0.182 \\
(2.45) \\
{[0.012]}\end{array}$ & $\begin{array}{c}0.331 \\
(1.28) \\
{[0.052]}\end{array}$ & $\begin{array}{c}0.387 \\
(2.11) \\
{[0.029]}\end{array}$ & $\begin{array}{c}0.284 \\
(1.92) \\
{[0.062]}\end{array}$ \\
\hline Number of employees & $G L_{i, t}$ & $\begin{array}{l}-0.0006 \\
(-2.98) \\
{[0.001]}\end{array}$ & $\begin{array}{c}-0.0012 \\
(-8.19) \\
{[0.000]}\end{array}$ & $\begin{array}{c}-0.0016 \\
(-4.22) \\
{[0.000]}\end{array}$ & $\begin{array}{c}-0.0007 \\
(8.10) \\
{[0.000]}\end{array}$ & $\begin{array}{c}-0.0010 \\
(-2.52) \\
{[0.010]}\end{array}$ & $\begin{array}{c}-0.0008 \\
(-2.67) \\
{[0.003]}\end{array}$ \\
\hline $\begin{array}{l}\text { Interaction between the firm equity the } \\
\text { stock market development }\end{array}$ & $S M F_{i, t}$ & $\begin{array}{c}0.048 \\
(4.01) \\
{[0.000]}\end{array}$ & $\begin{array}{c}0.031 \\
(2.33) \\
{[0.012]}\end{array}$ & $\begin{array}{c}0.015 \\
(1.72) \\
{[0.027]}\end{array}$ & $\begin{array}{l}0.059 \\
(3.18) \\
{[0.00]}\end{array}$ & $\begin{array}{c}0.115 \\
(1.59) \\
{[0.001]}\end{array}$ & $\begin{array}{l}-0.061 \\
(-1.12) \\
{[0.213]}\end{array}$ \\
\hline Firm's age & $A G E_{i, t}$ & $\begin{array}{l}-0.421 \\
(-6.82) \\
{[0.000]}\end{array}$ & $\begin{array}{l}-0.492 \\
(-4.55) \\
{[0.000]}\end{array}$ & $\begin{array}{l}-0.391 \\
(-7.85) \\
{[0.000]}\end{array}$ & $\begin{array}{c}-0.409 \\
(-11.72) \\
{[0.00]}\end{array}$ & $\begin{array}{l}-0.364 \\
(-7.57) \\
{[0.000]}\end{array}$ & $\begin{array}{l}-0.301 \\
(-6.32) \\
{[0.000]}\end{array}$ \\
\hline $\begin{array}{l}\text { Invers competition indicator (defined } \\
\text { as the ratio of ex-post rent to net sale) }\end{array}$ & $C O M_{i, t}$ & $\begin{array}{l}-0.391 \\
(-5.76) \\
{[0.000]}\end{array}$ & $\begin{array}{l}-0.213 \\
(-4.55) \\
{[0.000]}\end{array}$ & $\begin{array}{l}-0.352 \\
(-4.61) \\
{[0.000]}\end{array}$ & $\begin{array}{c}-0.368 \\
(-4.01) \\
{[0.000]}\end{array}$ & $\begin{array}{l}-0.491 \\
(-4.76) \\
{[0.000]}\end{array}$ & $\begin{array}{l}-0.332 \\
(-6.77) \\
{[0.000]}\end{array}$ \\
\hline Ownership concentration ratio & $O W N_{i, t}$ & $\begin{array}{c}0.192 \\
(4.98) \\
{[0.000]}\end{array}$ & $\begin{array}{c}0.119 \\
(3.88) \\
{[0.000]}\end{array}$ & $\begin{array}{c}0.112 \\
(4.76) \\
{[0.000]}\end{array}$ & $\begin{array}{c}0.274 \\
(5.86) \\
{[0.000]}\end{array}$ & $\begin{array}{c}0.221 \\
(5.01) \\
{[0.000]}\end{array}$ & $\begin{array}{c}0.149 \\
(6.97) \\
{[0.000]}\end{array}$ \\
\hline $\begin{array}{l}\text { Interaction between the firm's } \\
\text { dependence on debt finance and bank } \\
\text { sector de. }^{\text {d }}\end{array}$ & $D M F_{i, t}$ & & $\begin{array}{l}0.029 \\
(7.92) \\
{[0.000]}\end{array}$ & $\begin{array}{c}0.037 \\
(6.95) \\
{[0.000]}\end{array}$ & $\begin{array}{c}0.021 \\
(7.02) \\
{[0.000]}\end{array}$ & $\begin{array}{c}0.027 \\
(8.22) \\
{[0.000]}\end{array}$ & $\begin{array}{c}0.021 \\
(7.12) \\
{[0.000]}\end{array}$ \\
\hline $\begin{array}{l}D U M_{i, t} \text { Firm's size dummy variable } \\
\text { equal } 1 \text { if the firm is large }\end{array}$ & $S M F_{i, t} * D U M_{i, t}$ & & & $\begin{array}{c}0.293 \\
(6.99) \\
{[0.000]}\end{array}$ & & & \\
\hline & ${ }_{t} D M F_{i, t} * D U M_{i,}$ & & & $\begin{array}{l}-0.281 \\
(-0.662) \\
{[0.521]}\end{array}$ & & & \\
\hline $1^{\text {st }}$ Order serial correlation test ${ }^{\mathrm{e}}$ & $L M_{(l)}$ & {$[0.853]$} & {$[0.886]$} & {$[0.501]$} & {$[0.696]$} & {$[0.794]$} & {$[0.791]$} \\
\hline $2^{\text {st }}$ Order serial correlation test ${ }^{\mathrm{e}}$ & $L M_{(2)}$ & {$[0.260]$} & {$[0.231]$} & {$[0.712]$} & {$[0.394]$} & {$[0.278]$} & {$[0.292]$} \\
\hline Joint significance test & $J T$ & {$[0.000]$} & {$[0.000]$} & {$[0.000]$} & {$[0.000]$} & {$[0.000]$} & {$[0.000]$} \\
\hline Sargan Test ${ }^{\mathrm{f}}$ & $S T$ & [0.998] & {$[0.996]$} & {$[0.998]$} & [0.997] & [0.999] & [0.998] \\
\hline
\end{tabular}

Note. Numbers in parentheses are t-values and numbers in Brackets are P-value. This Table reports the GMM-DIFFERENCE regression, estimated by using DPD99 package for OX. Time dummies are included in all the regressions.

Notices: ${ }^{\text {a: }}$ the dependent variable in all models is the growth rates of value added. Value added is defined as operating profits after depreciation plus wages and interest payments. ${ }^{\text {b: }}$ In regressions from 1 to 3 , the stock market development is the market capitalisation ratio. ${ }^{\mathrm{c}}$ In regression 4, 5 and 6 the stock market development are total vale-traded ratio, turnover ratio and volatility, respectively. ${ }^{\text {d: }}$ the bank sector developments are the ratio of total assets to GDP and the private credit to GDP. ${ }^{\text {e: }} L M_{(k)}$ is the test statistic for the presence of k-th order serial correlation in the first-differenced residual, the null-hypothesis is that the errors in the first-difference regression exhibit no k-order serial correlation. ${ }^{\text {f: }}$ Sargan is a Sargan test of the over identifying restrictions, the null-hypothesis is that the instruments used are not correlated with residuals. The joint test statistic is a test of the joint significance of all independent variables.

\section{Conclusions and Policy Implications}

In this study MG constructed a simple dynamic firm growth empirical model in which stock market development and bank sector development affect firm growth mainly through enhancing productivity growth within the firm, provide a test on micro-level data of the hypothesis that the development of the stock market is a significant determent of economic growth in Saudi Arabia. In particular, MG using their model to investigates three issues. Firstly, whether the firms' that heavily depend on equity finance grow faster with the higher-level of the stock 
market development than firms that are not heavily dependent on equity finance. Secondly, whether the stock market is a substitute or a complement for the banking sector in providing financial services to the corporate sector in Saudi Arabia and whether the stock market or the banking sector is better in providing financial services and therefore enhancing growth in these firms. Thirdly, whether the performance of large and small firms in terms of growth react differently to the stock market and baking sector development.

In order to examine the pervious issues, $M G$ extends a simple empirical model that incorporates the financial market development effects and other variables that may affect the firms' growth. MG begin from a premise that financial markets provide mainly two critical functions to an economy; allocation of risk capital through saving mobilising and risk pooling and sharing and promotion of responsible governance and control through providing outside investors a variety of mechanism for monitoring inside decision makers. MG argued that these functions of financial markets influence firm performance by promoting technological innovations and inducing the efficiency with resources are utilised. MG use firm-level panel data for a sample of 28 Saudi Arabia industrial quoted companies covering the period 1995-2013. With this panel data set MG using the GMM dynamic panel technique with both a difference dynamic panel estimator developed by Arellano and Bond (1991) and a system dynamic panel estimator developed and studied by Arellano and Bover (1995), Blundell and Bond (1998a, 1998b) which mitigates some of the biases frequently found when using the difference dynamic panel estimator. Both types of estimators; the level of activity and the size of the stock market exert a statistically significant and economically large impact on the firms' growth. Furthermore, MG find results indicate that with more development in the stock market firms that use equity finance heavily grow faster than firms that do not. These findings provide firm-level support for the proposition that the development of the stock market facilitates economic growth in Saudi Arabia.

MG results also show that both the stock market and the banking sector development are significant in facilitating the firm's growth in Saudi Arabia. In particular, MG find that measures of both market and banking development independently predict firm's growth when entered together in firm growth regressions. Besides emphasising the strong link between the financial system and firm growth, this result confirms our findings that the stock market and banking sector in Saudi Arabia are complementary rather than substitutes in providing financial services to the corporate sector. They provide different financial services to the corporate sector. While, government polices to develop the stock market need not distinguish the importance of the banking sector. Finally, MG findings in this study have significant policy implications for the Saudi Arabia economy and other emerging markets beyond a similar economic structure. The results are consistent with the hypothesis that the stock market and the banking sector development have different effects on small and large firms. The evidence suggests that large firms are more sensitive to the stock market development, whereas small firms are more sensitive to variations in the banking sector development. Given that firms in developing countries make different corporate financing choices than their developed country counterparts largely due to differences in market conditions, this study also investigated the effect of these conditions on the corporate capital structure made by Saudi Arabia firms.

The study has successfully achieved its aims and answered its questions to explore and this study provides new and updated empirical investigate the effect of stock market development, bank development and firms growth in developing countries Saudi Arabia is wide open, while although as, all most study has limitations and these might be explored in future study based on the scope of the study. Keeping in mind the limitation, as this study should only be seen as a contribution to continue the stock market development, bank development and firms' growth in emerging economy study process in Saudi Arabia not as an end in itself. In addition, the most a significant limitation aspect is the availability of data. The small sample size company used in the macro-analysis since this study focuses on twenty eight companies whose main business activity is industrial investment business and they are listed on the Tadawul's stock market.

Future research is needed to meet up-to-date information regarding the nature of capital market and its financial institutions among the size enterprises of companies. Therefore, more study in this area is needed. At macro-level, future study could assess the effect of stock market development on capital accumulation, private savings rates and productivity growth. At micro-level, future study could investigate the causal relationship between stock market development and firms' investment rates, technical changes and economic efficiency.

\section{References}

Acemoglu, D., Philippe, A., \& Zilibotti, F. (2006). Distance to frontier, selection, and economic growth. Journal of the European Economic Association, 4(1), 37-74. http://dx.doi.org/10.1162/jeea.2006.4.1.37

Ahn, C., \& Schmidt, P. (1999). Estimation of linear panel data models using GMM. In L. Matyas (Ed.), 
Generalized method of moments estimation. New York: Cambridge University Press.

Anderson, T. W., \& Hsiao, C. (1981). Estimation of dynamic models with error components. Journal of the American Statistical Association, 76(375), 589-606. http://dx.doi.org/10.1080/01621459.1981.10477691

Anderson, T. W., \& Hsiao, C. (1982). Formulation and estimation of dynamic models using panel data. Journal of Econometrics, 18(1), 47-82. http://dx.doi.org/10.1016/0304-4076(82)90095-1

Andrews, D., \& Lu, B. (2001). Consistent model and moment selection procedures for GMM estimation with application to dynamic panel data models. Journal of Econometrics, 101(1), 123-164. http://dx.doi.org/10.1016/S0304-4076(00)00077-4

Appelbe, T., Dineen, C., Solvason, D., \& Hsiao, C. (1992). Econometric modelling of Canadian long distance calling: a comparison of aggregate time series versus point-to-point panel data approaches. In B. Raj \& B. Baltagi (Eds.), Panel data analysis. Germany: Physica-Verlag Heidelberg. http://dx.doi.org/10.1007/978-3-642-50127-2_10

Arellano, M., \& Bond, S. (1991). Some tests of specification for panel data: Monte Carlo evidence and an application to employment equations. Review of Economic Studies, 58(2), 277-297. http://dx.doi.org/10.2307/2297968

Arellano, M., \& Bover, O. (1995). Another look at the instrumental variable estimation of error-components models. Journal of Econometrics, 68(1), 29-51. http://dx.doi.org/10.1016/0304-4076(94)01642-D

Ariyo, A., \& Adelegan, O. (2005). Assessing the impact of capital market reforms in Nigeria an incremental approach. Paper presented at the 46th Annual Conference of the Nigeria Economic Society in Lagos.

Atje, R., \& Jovanovic, B. (1993). Stock markets and development. European Economic Review, 37(2/3), 632640. http://dx.doi.org/10.1016/0014-2921(93)90053-D

Bagehot, W. (1873). Lombard street: A description of the money market. In M. John (Ed.), Reprinted (with introduction by Hartley Withers). London: William Clowes \& Sons.

Baltagi, H. B., Li, D., \& Li, Q. (2007). Transaction tax and stock market behaviour: Evidence from an emerging market. Empirical Economics, 31(2), 393-408. http://dx.doi.org/10.1007/s00181-005-0022-9

Barro, R. (1998). Notes on growth accounting. Working Paper No. 6654, National Bureau of Economic Research, Cambridge,

MA.

Retrieved

from http://citeseerx.ist.psu.edu/viewdoc/download?doi=10.1.1.201.4114\&rep=rep1\&type=pdf

Beck, T., \& Levine, R. (2000). New firm formation and industry growth-does having a market or bank-based system matter? (pp. 1-50) Policy Research, Working Paper Series, No. 2383. http://dx.doi.org/10.1596/1813-9450-2609

Beck, T., \& Levine, R. (2002). Stock markets, banks and growth: Panel evidence. NBER Working Paper Series. No. 9082, Cambridge, Mass: National Bureau of Economic Research. Retrieved from http://dept.ku.edu/ empirics/Courses/.../stock-mkt-bank-growth_jbf04.pdf

Beck, T., Demirgüç-Kunt, A., \& Levine, R. (1999). A new database on financial development and structure. Working Paper No. 2146, World Bank Policy Research. Retrieved from http://www.worldbank.org/finance/assets/images/fs02_web.pdf

Bekaert, G., Harvey, C. R., \& Lundblad, C. (2005). Does financial liberalisation spur growth. Journal of Financial Economics, 77(1), 3-55. http://dx.doi.org/10.1016/j.jfineco.2004.05.007

Bencivenga, V. R., \& Smith, B. D. (1991). Financial intermediation and endogenous growth. Review of Economic Studies Limited, 58(2), 195-209. http://dx.doi.org/10.2307/2297964

Bhide, A. (1993). The hidden cost of stock market liquidity. Journal of Financial Economics, 34(1), 31-51. http://dx.doi.org/10.1016/0304-405X(93)90039-E

Blackburn, K., \& Hung, V. T. Y. (1998). A theory of growth, financial development, and trade. Economica, New Series, 65(257), 107-124. http://dx.doi.org/10.1111/1468-0335.00116

Blundell, R., \& Bond, S. (1998a). GMM estimation with persistent panel data: an application to production functions. Working Paper No. 4, the Institute for Fiscal Studies, London. Retrieved from http://discovery.ucl.ac.uk/14817/1/14817.pdf

Blundell, R., \& Bond, S. (1998b). Initial conditions and moment restrictions in dynamic panel data models. Journal of Econometrics, 87(1), 29-52. http://dx.doi.org/10.1016/S0304-4076(98)00009-8 
Blundell, R., Bond, S., \& Windmeijer, F. (2000). Estimation in dynamic panel data models: improving on the performance of the standard GMM estimators. Working Paper, the Institute for Fiscal Studies; London. Retrieved from http://eprints.ucl.ac.uk/4070/1/4070.pdf

Bond, S., Harhoff, D., \& Reenen, J. (1999). Investment, $R \& D$ financial constraints in Britain and Germany. Working Paper, the Institute for Fiscal Studies; London. Retrieved from http://www.nber.org/criw/papers/vanreenen.pdf

Bottazzi, G., Secchi, A., \& Tamagni, F. (2006). Financial fragility and growth dynamics of Italian business firms. LEM Working Paper, Sant'Anna School of Advanced Studies, Pisa, Italy. Retrieved from http://www.lem.sssup.it/WPLem/files/2006-07.pdf

Boyd, J. H., \& Smith, B. D. (1998). The co-evolution of the real and financial sectors in the growth process (pp. 1-43). Working $\quad$ Papers, $541 . \quad$ Retrieved http://elibrary.worldbank.org/doi/abs/10.1093/wber/10.2.371?journalCode=wber

Boyd, J. H., \& Prescott, E. (1986). Financial intermediary-coalitions. Journal of Economic Theory, 38(2), 21132. http://dx.doi.org/10.1016/0022-0531(86)90115-8

Cetorelli, N., \& Gamberra, M. (2000). Banking market structure, financial dependence and growth: International evidence from industry data. Working Paper, Federal Reserve Bank of Chicago. Retrieved from http://fic.wharton.upenn.edu/fic/papers/00/0019.pdf

Chamberlian, G. (1984). Panel data. In Griliches, Z., \& Intriligator, M. (Eds.), Handbook of Econometrics. Amsterdam: Elsevier.

Cobham, D. (1995). Financial systems for developing countries, with particular reference to Egypt, Iraq, Jordan, Lebanon, and Syria. In Economic Research Form for the Arab Countries, Iran, and Turkey (Ed.), Development of Financial Markets in the Arab Countries, Iran and Turkey, Economic Research Forum for the Arab Countries, Iran, and Turkey, Cairo.

Collier, P., \& Maryer, Y. (1989). The assessment: financial liberalisation, financial systems, and economic growth. Oxford Review of Economic Policy, 5(4), 1-12. http://dx.doi.org/10.1093/oxrep/5.4.1

Das, S. (1995). Size, age and firm growth in an infant industry: The computer hardware industry in India. International Journal of Industrial Organisation, 13(1), 111-126. http://dx.doi.org/10.1016/0167-7187(94)00453-9

Davidsson, P., \& Henrekson, M. (2000). Institutional determinants of the prevalence of start-ups and high-growth firms: Evidence from Sweden. Book Working Paper, University of Stockholm.

Deidda, L., \& Crenos, D. (2000). Interaction between economic and financial development. Journal of Monetary Economics, 53(2), 233-248. http://dx.doi.org/10.1016/j.jmoneco.2005.03.007

Delmar, F. (1997). Measuring growth: methodological considerations and empirical results. In Donckels, R., \& Miettinen, A. (Eds.), Entrepreneurship and SME research: On its way to the next millennium. UK: Aldershot.

Demirgüç-Kunt, A., \& Huizinga, H. (2000). Financial structure and bank profitability policy research. Working Paper, the World Bank. Retrieved from http://elibrary.worldbank.org/doi/book/10.1596/1813-9450-2430

Demirgüç-Kunt, A., \& Levine, R. (1996). Stock market, corporate finance and economic growth: An overview. World Bank Economic Review, 10(2), 223-239. http://dx.doi.org/10.1093/wber/10.2.223

Demirgüç-Kunt, A., \& Levine, R. (2008). Finance, financial sector policies and long-run growth. World Bank Policy, 4469, 1-82. Retrieved from http://elibrary.worldbank.org/doi/pdf/10.1596/1813-9450-4469

Demirgüç-Kunt, A., \& Maksimovic, V. (1996). Financial constraints, uses of funds, and firm growth: An international comparison. World Bank Policy Research Paper, 1671. Retrieved from http://ssrn.com/abstract=10202

Demirgüç-Kunt, A., \& Maksimovic, V. (1998). Law, finance and firm growth. Journal of Finance, 53(6), 21072137. http://dx.doi.org/10.1111/0022-1082.00084

Demirgüç-Kunt, A., \& Maksimovic, V. (2001). Funding growth in bank-based and market-based financial systems: Evidence from firm level data. Policy Research, Working Paper, 20433, World Bank, Washington, D.C. Retrieved from http://www.rhsmith.umd.edu/faculty/vmax/papers/jfe2002.pdf

Doorenik, J., Arellano, M., \& Bond, S. (1999). Panel data estimation using DPD for OX. University of Oxford. 
Dow, J., \& Gorton, G. (1995). Profitable informed trading in a simple general equilibrium model of asset pricing. Journal of Economic Theory, 67(2), 327-369. http://dx.doi.org/10.1006/jeth.1995.1077

Dow, J., \& Gorton, G. (1997). Stock market efficient and economic efficiency: Is there a connection? Journal of Finance, 52(3), 1087-1129. http://dx.doi.org/10.1111/j.1540-6261.1997.tb02726.x

Dune, T., \& Hughes, A. (1994). Age, size, growth and survival: UK companies in the 1980s. Journal of Industrial Economics, 42(2), 115-140. http://dx.doi.org/10.2307/2950485

Estrada, G., Park, D., \& Kamayandi, A. (2010). Financial development and economic growth in developing Asia. ADB Working Paper, $233 . \quad$ Retrieved from $\mathrm{http}: / / \mathrm{www} \cdot a \mathrm{adb}$. org/publications/financial-development-and-economic-growth-developing-asia

Ewah, S. O. E., Essang, A. E., \& Bassey, J. U. (2009). Appraisal of capital market efficiency on economic growth in Nigeria. International Journal of Business and Management, 4(12), 219-225. Retrieved from http://www.ccsenet.org/journal/index.php/ijbm/article/view/4517

Fry, M. J. (1978). Money and capital or financial deepening in economic development? Journal of Money, Credit and Banking, 10(4), 464-475. http://dx.doi.org/10.2307/1991576

Fry, M. J. (1980). Money, interest, inflation and growth in Turkey. Journal of Monetary Economics, 6(4), 535545. http://dx.doi.org/10.1016/0304-3932(80)90006-9

Fry, M. J. (1988). In defence of financial liberalisation. Economic Journal, 107, 754-770. http://dx.doi.org/10.1111/j.1468-0297.1997.tb00041.x

Galbis, V. (1977). Financial intermediation and economic growth in less-developed countries: A theoretical approach. Journal of Development Studies, 13(2), 58-72. http://dx.doi.org/10.1080/00220387708421622

Goldsmith, R. W. (1969). Financial structure and development. New Haven, CT: Yale University Press.

Greenwood, J., \& Jovanovic, B. (1990). Financial development, growth and the distribution of income. Journal of Political Economy, 98(5), 1076-2007. http://dx.doi.org/10.1086/261720

Greenwood, J., \& Smith, B. (1997). Financial markets in development and the development of financial markets. Journal of Economic Dynamic and Control, 21(1), 145-181. http://dx.doi.org/10.1016/0165-1889(95)00928-0

Griliches, Z., \& Hausman, J. A. (1986). Errors in variables in panel data. Journal of Econometrics, 32, 93-118. http://dx.doi.org/10.1016/0304-4076(86)90058-8

Gurley, J. G., \& Shaw, E. S. (1955). Financial aspects of economic development. American Economic Review, 45(4), 515-538. Retrieved from http://www.jstor.org/stable/1811632

Hair, J. F., Anderson, R. E., Tatham, R. L., Black, W. C., \& Bain, B. J. (2009). Multivariate data analysis. Prentice Hall: Upper Saddle River.

Hansen, L. (1982). Large sample properties of generalised method of moment estimator. Econometrica, 50(4), 1029-1054. http://dx.doi.org/10.2307/1912775

Hao, S., Jin, Q., \& Zhang, G. (2011). Relative firm profitability and stock return sensitivity to industry-level. News Accounting Review, 86(4), 1321-1347. http://dx.doi.org/10.2308/accr-10042

Harrise, R. G. (1997). Stock markets and development: A re-assessment. European Economic Review, 41(1), 139-146. http://dx.doi.org/10.1016/S0014-2921(96)00021-9

Heshmmati, A. (2001). On the growth of micro and small firms: Evidence from Sweden. Small Business Economics, 17(3), 213-228. http://dx.doi.org/10.1023/A:1011886128912

Hoberg, G., \& Phillips, G. (2012). The stock market, product uniqueness, and comovement of peer firms. Working Papers Series. http://dx.doi.org/10.2139/ssrn.2160846

Holtz-Eakin, D., Newey, W., \& Rosen, H. (1990). Estimating vector autoregressions with panel data. Econometrica, 56(6), 1371-1395. http://dx.doi.org/10.2307/1913103

Hsiao, C. (1985). Benefits and limitations of panel data. Econometric Reviews, 4(1), 121-174. http://dx.doi.org/10.1080/07474938508800078

Hsiao, C. (1986). Analysis of panel data. New York: Cambridge University Press.

Huybens, E., \& Smith, B. (1998). Financial market frictions, monetary policy and capital accumulation in a small open economy. Journal of Economic Theory, 81(2), 353-400. http://dx.doi.org/10.1006/jeth.1997.2372 
Islam, N. (1998). Growth empirics: A panel data approach. Quarterly Journal of Economics, 113(1), 325-329. http://dx.doi.org/10.1162/003355398555513

Jappelli, T., \& Pagano, M. (1994). Saving, growth, and liquidity constraints. Quarterly Journal of Economics, 109(1), 83-109. http://dx.doi.org/10.2307/2118429

Johannes, T. A., Njong, A. M., \& Cletus, N. (2011). Financial development and economic growth in Cameroon, 1970-2005. Journal of Economics and International Finance, 3(6), 367-375. Retrieved from http://www.psrcentre.org/images/extraimages/413556.pdf

Johnston, J., \& DiNardo, J. (1997). Econometric methods. McGraw Hill, University of Wisconsin-Madison.

Kapur, B. K. (1976). Alternative stabilization policies for less developed economics. Journal of Political Economy, 84(4), 777-795. http://dx.doi.org/10.1086/260476

King, R. G., \& Levine, R. (1993). Financial, entrepreneurship and growth: Theory and evidence. Journal of Monetary Economics, 32(3), 513-542. http://dx.doi.org/10.1016/0304-3932(93)90028-E

Kyle, A. S. (1984). A theory of futures market manipulations. In A. Ronald (Ed.), The industrial organisation of futures markets (pp. 141-174). Lexington, MA: Lexington Books.

Lee, K., Pesaran, M., \& Smith, R. (1998). Growth empirics: A panel data approach: A comment. Quarterly Journal of Economics, 113(1), 319-323. http://dx.doi.org/10.1162/003355398555504

Levine, R. (1991). Stock market, growth, and tax policy. Journal of Finance, 46(4), 1445-1465. http://dx.doi.org/10.1111/j.1540-6261.1991.tb04625.x

Levine, R. (1997). Financial development and economic growth: Views and agenda. Journal of Economic Literature, 35(2), 688-626. Retrieved from http://www.jstor.org/stable/2729790

Levine, R. (2003). More on finance and growth: more finance, more growth? The Federal Reserve Bank of St. Louise Review, July-August, 31-46. Retrieved from http://www.research.stlouisfed.org/publications/review/03/07/Levine.pdf

Levine, R., \& Zervos, S. (1996). Stock market development and long-run growth. World Bank Economic Review, 10(2), 323-339. http://dx.doi.org/10.1093/wber/10.2.323

Levine, R., \& Zervos, S. (1998). Capital control liberalisation and stock market development. World Development, 26(7), 1169-1184. http://dx.doi.org/10.1016/S0305-750X(98)00046-1

Levine, R., Loayza, N., \& Beck, T. (2000). Financial intermediation and growth: Causality and causes. Journal of Monetary Economics, 46(1), 31-77. http://dx.doi.org/10.1016/S0304-3932(00)00017-9

Liu, L. Y. (2002). Reforming china's urban health insurance system. Health Policy, 60(2), 133-150. http://dx.doi.org/10.1016/S0168-8510(01)00207-X

Masoud, N., \& Hardaker, G. (2012). The impact of financial development on economic growth: Empirical analysis of emerging market countries. Studies in Economics and Finance, 29(3), 148-173. http://dx.doi.org/10.1108/10867371211246830

Matyas, L. (1999). Generalised method of moment estimation. New York: Cambridge University Press.

McKinnon, R. I. (1973). Money and capital in economic development. Washington, DC: Brookings Institution.

Nerlove, M. (2000). Growth rate convergence, fact or artefact? An essay on panel data econometrics. In Krishnakumar, J., \& Ronchetti, E. (Eds.), Panel data econometrics: Future directions. North-Holland: Amsterdam.

Nickell, S. J. (1996). Competition and corporate performance. Journal of Political Economy, 104(4), 724-746. http://dx.doi.org/10.1086/262040

Pagano, M., Panetta, F., \& Zingales, L. (2002). Why do companies go public? An empirical analysis. Journal of Finance, 53(1), 27-64. http://dx.doi.org/10.1111/0022-1082.25448

Patrick, H. T., \& Wai, U. (1973). Stock and bond issues and capital markets in less developed countries. International Monetary Fund, Staff Papers, 20(2), 253-317. Retrieved from http://www.jstor.org/stable/3866321

Peterson, M. A., \& Rajan, R. R. (1995). The effect of credit market competition on lending relationship. The Quarterly Journal of Economics, 110(2), 407-443. http://dx.doi.org/10.2307/2118445

Rajan, R. G. (1992). Insiders and outsider: The choice between informed and arm's length debt. Journal of 
Finance, 47(4), 1367-1400. http://dx.doi.org/10.1111/j.1540-6261.1992.tb04662.x

Rajan, R. G., \& Zingales, L. (1995). What do you know about capital structure? Some evidence from international data. Journal of Finance, 50(5), 1421-1460. http://dx.doi.org/10.1111/j.1540-6261.1995.tb05184.x

Rajan, R. G., \& Zingales, L. (1998). Financial development and growth. American Economic Review, 88(3), 559-586. Retrieved from http://www.nber.org/papers/w5758

Rogers. P., Ribeiro, K. C. S., \& Securato, J. R. (2008). Corporate governance, stock market and economic growth Brazil. Corporate Ownership and Control, 6(2), 222-237. Retrieved from $\mathrm{http}: / /$ ssrn.com/abstract $=953307$

Rousseau, P. L., \& Wachhtel, P. (2000). Equity markets and growth: Cross country evidence on timing and outcomes. Journal of Banking and Finance, 24(12), 613-622. http://dx.doi.org/10.1016/S0378-4266(99)00123-5

Saint-Paul, G. (1992). Technological choice, financial markets and economic development. European Economic Review, 36(4), 763-781. http://dx.doi.org/10.1016/0014-2921(92)90056-3

Sargan, J. D. (1958). The estimation of economic relationships using instrumental variable. Econometrica, 26(3), 393-415. http://dx.doi.org/10.2307/1907619

Saudi Arabia Stock Market (TASI). (2014). Tadawul. Retrieved from http://www.tadawul.com. sa

Schumpeter, A. (1912). The theory of economic development. Cambridge. AM: Harvard University Press.

Schumpeter, J. (1973). The theory of economic development. Cambridge, Mass: Harvard University Press.

Shaw, E. (1973). Financial Deepening in Economic Development. New York: Oxford University Press.

Shin, H. H., \& Stulz, R. M. (2000). Firm value, risk, and growth opportunities (pp. 1-35). Dice Center Working Paper, 8. http://dx.doi.org/10.2139/ssrn.234344

Singh, A. (1993). The stock market and economic development: Should developing countries encourage stock markets? UNCTAD Review, 4, 1-28. Retrieved from http://cedeplar.ufmg.br/economia/disciplinas/ecn933a/crocco/Criacao_expansao_mercado_capitais/SINGH $\sim 31$.PDF

Singh, A. (1996). Pension reform, the stock market, capital formation and economic growth: A critical commentary on the World Bank's proposals. Centre for Economic Policy Analysis, Working Paper No. 2, New York.

Singh, A. (1997). Financial liberalisation, stock markets and economic development. Economic Journal, 107(442), 771-782. http://dx.doi.org/10.1111/j.1468-0297.1997.tb00042.x

Singh, A. (1999). Should Africa promote stock market capitalism? Journal of Informational Development, 11(3), 343-365.

Singh, A., \& Weisse, B. (1998). Emerging stock markets, portfolio capital flows and long-term economic growth: Micro and macroeconomic perspectives. Journal World Development, 26(4), 607-622. http://dx.doi.org/10.1016/S0305-750X(98)00003-5

Siqueira. E., Otuki. T., \& Costa, Jr. N. (2012). Stock return and fundamental variables: A discriminant analysis approach. Applied Mathematical Sciences, 6(115), 5719-5733. Retrieved from http://www.m-hikari.com/ams/ams-2012/ams-113-116-2012/dacostaAMS113-116-2012.pdf

Stiglitz, J. (1985). Credit markets and the control of capital. Journal of Money, Credit and Banking, 17(2), 133152. http://dx.doi.org/10.2307/1992329

Stiglitz, J. (1989). Financial markets and development. Oxford Review of Economic Policy, 5(4), 55-68. http://dx.doi.org/10.1093/oxrep/5.4.55

Stock, J. H. (2001). Macro-econometrics. Journal of Econometrics, 100(1), 29-32. http://dx.doi.org/10.1016/S0304-4076(00)00049-X

Storey, D. (1994). Understanding the small business sector. London: Routledge.

Stulz, R. (2000). Financial structure, corporate finance and economic growth. International Review of Finance, 1(1), 11-38. http://dx.doi.org/10.1111/1468-2443.00003

Tachiwou, A. M. (2010). Stock market development and economic growth: The case of West African monetary 
union. International Journal of Economics and Finance, 2(3), 97-103. Retrieved from http://ccsenet.org/journal/index.php/ijef/article/view/6824

Tadawul. (2000, 2011, 2012). Annual Statistical Report. Riyadh: Saudi Stock Exchange.

Tadawul. (2009). Magazine. Riyadh: Saudi Stock Exchange. 27th-38th issues.

Tadawul. (2010). Magazine. Riyadh: Saudi Stock Exchange. 28th-50th issues.

World Bank. (1989). Financial Systems and Development. New York, NY: Oxford University Press.

\section{Notes}

Note 1. These capital market imperfections can take numerous forms. Technological and incentive frictions can exist, which prevent individuals from having access to economic of scale, increase the costs of acquiring information, increase asymmetric information and create incomplete contracts. In addition, restriction on international capital flows, lack of international market integration and high transaction costs will effect the efficient allocation of capital.

Note 2. The relationship between financial development and economic growth has received considerable attention in economic growth literature during past decades which can be traced back to the work of Schumpeter (1973), Shaw (1973) and others (see e.g., Bagehot, 1873; Schumpeter, 1912; Gurley \& Shaw, 1955; Goldsmith, 1969; Mckinnon, 1973; Kapur, 1976; Galbis, 1977; Fry, 1978, 1980, 1988; Estrada et al., 2010; Johannes et al., 2011; among others). For comprehensive review see also; World Bank (1989), Levine (1997), Liu (2002), Masoud and Hardaker (2012).

Note 3. Rajan (1992, p. 1367) states, "[...] .The firm's choice of borrowing sources [bank and bond finances] and the choice of priority for its debt claims attempt to optimally circumscribe the powers of banks".

Note 4. The error term in our model, Eq. 5, has three components: unobserved firm specific effects, time-specific effects and the standard innovation error term. In order to get consistent estimators Arellano and Bond (1991) propose to first-difference the regression equation to eliminate the unobserved firm fixed effects.

Note 5. Rents are defined as: profit before tax + depreciation + interest payments - (cost of capita * capital stock).

Note 6. For Saudi Arabia companies, rate of depreciation, $\delta$, to $12 \%$, has been drawn up by the tax department of Saudi Arabia.

Note 7. The growth differential is calculated as: 0.071 (the coefficient of the interaction term of the stock market development indicator and equity dependence) $* 0.81$ (equity dependence of the SAUDI INTERNATIONAL PEROCHEMICAL CO. minus equity dependence of the ALABDULLATIF INDUSTRIAL INVESTMENT) * 0.63 (the stock market development indicator, market capitalisation ratio).

Note 8. More detail discussed how more liquidity in stock markets can facilities technological advances (see Masoud \& Hardaker, 2012).

\section{Copyrights}

Copyright for this article is retained by the author(s), with first publication rights granted to the journal.

This is an open-access article distributed under the terms and conditions of the Creative Commons Attribution license (http://creativecommons.org/licenses/by/3.0/). 